Summer 2013

\title{
The Future of Societal Constitutionalism in the Age of Acceleration
}

Riccardo Prandini

University of Bologna, riccardo.prandini@umibo.it

Follow this and additional works at: https://www.repository.law.indiana.edu/ijgls

Part of the Constitutional Law Commons, and the International Law Commons

\section{Recommended Citation}

Prandini, Riccardo (2013) "The Future of Societal Constitutionalism in the Age of Acceleration," Indiana Journal of Global Legal Studies: Vol. 20 : Iss. 2 , Article 8.

Available at: https://www.repository.law.indiana.edu/ijgls/vol20/iss2/8

This Symposium is brought to you for free and open access by the Law School Journals at Digital Repository @ Maurer Law. It has been accepted for inclusion in Indiana Journal of Global Legal Studies by an authorized editor of Digital Repository @ Maurer Law. For more information, please contact rvaughan@indiana.edu.

\section{$\Psi$}

JEROME HALL LAW LIBRARY

$$
\begin{aligned}
& \text { INDIANA UNIVERSITY } \\
& \text { Maurer School of Law }
\end{aligned}
$$




\title{
The Future of Societal Constitutionalism in the Age of Acceleration
}

\author{
RICCARDO PRANDINI*
}

\begin{abstract}
The aim of this article is to reframe the debate on societal constitutionalism and constitutionalization from a spatial to a temporal framework. This analytical shift is due to the dramatic acceleration of societal processes, which are increasingly crossing the spatial boundaries of nation-states and of all the other social structures embedded in peculiar places. This high-speed society is characterized by the so-called temporalization of complexity, which influences every aspect of social life and, in particular, the "validity" of law. On the basis of this theoretical background, I would like to show that changing the form of observation from a spatial to a temporal framework may help in understanding the future of constitutionalism in a different and creative way. To cite some of the examples presented in this article, such shifts in the form of observation could help us to reconsider: (a) why so many scholars prefer now to talk about "processes" of constitutionalization instead of constitutions as "structures"; (b) the growing relevance of courts instead of legislative bodies for processes of global constitutionalization; (c) the blurring or vanishing of the modern distinction between pouvoir constituant/pouvoir constitué; and (d) the fundamental role of human rights and dignity within the processes of global constitutionalization. The temporalization of constitutions could help us to understand and foresee a new and emerging ideal of societal constitutionalism in which the processes and structures of the structural coupling between (not national) polities and law are open to the challenges of a hyper-complex world society.
\end{abstract}

"Sleep faster, Comrade"

Soviet Joke

* Riccardo Prandini is Associate Professor of Sociology at the School of Political Sciences, University of Bologna. Correspondence to riccardo.prandini@unibo.it

Indiana Journal of Global Legal Studies Vol. 20, Issue 2 (2013)

(C) Indiana University Maurer School of Law 
Horizon: "an apparent line separating the sky from the earth, (which retreats as one approaches it)"

Oxford English Dictionary

\section{Tempus Fugit! Modern Constitutions as Ideal And Progressive LEGAL-POLITICAL DEVICES}

What is the right time for constitutionalism and the global emergence of civil global constitutions? Is our time a good time for global constitutionalism? How are the past, the present, and the future of constitutions bound together (or not)? Can we still observe a stable identity between modern constitutions and present-day ones? These are some of the many questions we could ask in order to reframe the subject of constitutionalism within the boundaries of a time perspective. ${ }^{1}$ Puzzlingly enough, the huge and increasingly specialized debate on global constitutions has never clearly focused on the concept of "time." Yet, the most modern constitutions emerged during a revolutionary and groundbreaking time (revolution as "accelerated" history) ${ }^{2}$ in which law and politics evolved in opposition to their traditional and customary features. Modernity itself is a Neuzeit, a denaturalized time, ${ }^{3}$ a time subjected to the "law of acceleration," where everything changes faster than could ever have been expected. ${ }^{5}$

For Hermann Lubbe, one of the most quoted scholars in the debate about acceleration, modern time is characterized by the "contraction of the present." He distinguishes the past as that which no longer holds/is no longer valid, while he identifies the future as that which does not yet hold/is not yet valid. He denotes the present as the time span for which the horizons of experience and expectation coincide. Only if this coincidence is valid can we use the present as a compass for the future.

1. See generally The Twilight of Constitutionalism? (Petra Dobner \& Martin Loughlin eds., 2010).

2. See generally Reinhart Koselleck, Is There an Acceleration of History?, in High-SPEED SOCIETY: SOCIAL ACCELERATION, POWER, AND MODERNITY 113 (Hartmut Rosa \& William E. Scheuerman eds., 2009).

3. See generally ReINHART Koselleck, Futures Past: ON THE SEMANTICS OF HistoriCAL TIME 222.54 (Keith Tribe trans., Colum. Univ. Press 2004) (1979).

4. Henry Adams, a historian and literary man, grasped the centrality of social acceleration. In 1904, he formulated a "law of acceleration," posing the question of what significance tradition and past history might come to possess in high-speed society. See generally THE EDUCATION OF HENRY ADAMS: AN AUTOBIOGRAPHY (1918).

5. The following sources provide an introduction to the relevance of acceleration and provide a bibliography collection. See generally HARTMUT ROSA, ALIENATION AND ACCEleration: TOWARDS A Critical TheORY OF LATE-Modern TEMPorality (2010) [hereinafter ALIENATION]; Hartmut Rosa \& William E. Scheuerman, Introduction to High-SPEed SOCIETY: SOCLAL ACCELERATION, POWER, AND MOdERNITY, supra note 2, at 1. 
Social acceleration can be defined by an increase in the decay rates of the reliability of experiences and expectations and by the contraction of time spans definable as the present, or, in simpler terms, as the quantity of innovations per unit of time in every social domain: "In a dynamic civilization, the quantity of civilizational elements that are still contemporary, but already on the verge of being out of date or antiquated, increases. Put differently, the non-contemporaneity of the contemporary increases in dynamic civilization."6

Reinhart Koselleck, the most important observer of temporal semantics, believed that since the French and Industrial Revolutions, social structures are changing faster than before, and structural change itself has become an "event": structures become an event ("die Strukturen werden zum Ereignis'). ${ }^{7}$ This accelerated historical time has led modern Western societies toward a growing separation between the "space of experiences" and the "horizon of expectations," where the former becomes increasingly "poor," short, and incapable of cultural consolidation, and the latter becomes distant, not deducible, and inaccessible: the future, conceived as horizon, cannot become the present, because it slips into a future past. ${ }^{8}$ As Niklas Luhmann has said, "the future cannot begin," ${ }^{9}$ and modernity has to face the problem "of assimilating experiences which could no longer be inferred from previous experience; and thus, accordingly, the formulation of expectations which could not have been nurtured previously." 10 Within modernity, time began to accelerate and social acceleration, defined as "an increase in the decay rates of the reliability of experiences and expectations and by the contraction of the time spans definable as the "present'[,]"11 became the problem. This acceleration was also fundamental for constitutions and constitutionalism because historically they represented a clear "vision" of progress, i.e, a tendency to link the present with the future, the immanence with the transcendence, the

6. Hermann Lübbe, The Contraction of the Present, in HigH-SPEED SOCIETY: SOCIAL ACCELERATION, POWER, AND MODERNITY, supra note 2, at 159, 161.

7. See generally REINHART KOSELLECK, Die unbekannte Zukunft und die Kunst der Prognose [The Unknown Future and the Art of Prognosis], in ZEITSCHICHTEN: STUDIEN ZUR HISTORIK [TIME-LAYERS: STUDIES ON THE SCIENCE OF HISTORY] 203, 221 (2000) (Ger.).

8. See generally KOSELLECK, supra note 3, at 255-76.

9. Niklas Luhmann, The Future Cannot Begin: Temporal Structures in Modern Society, 43 Soc. RES. 130 (1976).

10. KoSELLECK, supra note 3, at 268.

11. Hartmut Rosa, Social Acceleration: Ethical and Political Consequences of a Desynchronized High-Speed Society, in High-SPEed SocieTY: SocIAL ACCELERATION, POWER, AND MODERNITY, supra note 2, at 83-84. 
earth with the sky to touch the horizon. ${ }^{12}$ For the same reason, Koselleck precisely underlined that

[a]ll concepts of movement share a compensatory effect, which they produce. The lesser the experiential substance, the greater the expectations joined to it. The lesser the experience, the greater the expectation: this is a formula for the temporal structure of the modern, to the degree that it is rendered a concept by 'progress.' 13

Modern constitutionalism was, accordingly, a way to "idealize" and "project" into the future a new form of coupling between law and politics: law became positive law, speeding up procedures to fix and change itself through auto-reference; politics lost each and every connection with ascribed roles and started to operate using the government-opposition code, which is the simplest way to "futurize" and legitimize its structures. ${ }^{14}$ In that sense, republicanism represented a concept of movement, which did for political action what "progress" promised to do for the whole of history. Koselleck ultimately demonstrated that

[t]he old concept of 'republic,' which had previously indicated a condition, became a telos, and was at the same time rendered into a concept of movement by means of the suffix 'ism.' It served the purpose of theoretically anticipating future historical movement and practically influencing it. The temporal difference between all previously experienced forms of rule and the constitution that was to be expected and toward which one should strive was in this way embodied in a concept that had a direct influence on political life. ${ }^{15}$

12. See, e.g., James Tully, Strange Multiplicity: Constitutionalism in an Age of DIVERSITY (1995); SHELdON S. WOLIN, POLITICS AND VISION: CONTINUITY AND INNOVATION in Western Political Thought (1960); Sheldon S. Wolin, The Presence of the Past: Essays on the STATE AND the Constitution (1990); Richard S. Kay, Constitutional Chrononomy, 13 RATIO JURIS 31 (2000). For the framing of modern constitutionalism into the "struggle" between facts and norms, facticity and ideality, see generally S.N. EISENSTADT, The GREat REVolutrons AND THE Civilizations OF MODERnity (2006).

13. KOSELLECK, supra note 3 , at 274.

14. See Niklas Luhmann, Verfassung als evolutionäre Errungenschaft [Constitution as an Evolutionary Accomplishment], 9 RECHTSHISTORICHES JOURNAL [LEGAL HISTORY JOURNAL] 176 (1990) (Ger.).

15. KOSELLECK, supra note 3 , at 273 (emphasis added). 
Modern constitutions were embedded into a new and progressive temporal semantic, where the past represented only ancient times needing to be overcome, the present represented the time where constituent powers might have disclosed their revolutionary thrust, and the future represented the ideal image of a new society. ${ }^{16}$ That is why from the early days of modern constitutionalism, the problem of stability/change was so strongly debated. ${ }^{17}$

Are contemporary generations entitled to frame the future of the next ones? What kind of procedures must the constituent powers adopt in order to change what is "unchangeable" at one stroke? Is it rational to constrain and freeze the future of a nation? After the Second World War, constitutionalism seemed to colonize the whole sociopolitical scape, and these questions disappeared from the debate. ${ }^{18}$ The new problem became how to export and establish the culture of constitutionalism everywhere (even where the structural and cultural prerequisites of constitutions were fully absent) - even if this took a lot of time. ${ }^{19}$ Especially in politically and socially fractured nation-states, the future of the constitution was discounted to find ways to reconstruct (or invent) a common and viable past so as to reframe a livable present. ${ }^{20}$ The

16. Mark Tushnet, The New Constitutional Order (2003); Bill Kissane, New BeginNings: CONSTITUtionalism AND DEMOCRACY IN MODERN IRELAND (2011). The literature about constitutions as a "new beginning" is well developed, especially concerning constitution building processes in Africa.

17. See generally Stephen Holmes, Passions and Constraint: On the Theory of LIBERAL DEMOCRACY (1995) (describing the early debates on temporal limits of constitutions); Michael LiENESCH, NEW ORDER of the AGES: TIMe, THE Constitution, and the Making of Modern American Political Thought (1988) (describing the introduction of a new cultural timeframe in the U.S. Constitution); ROBERT JUSTIN LIPKIN, Constitutional Revolutions: Pragmatism and the Role of Judicial Review in AMERICAN CONSTITUTIONALISM (2000) (describing the role of constitutional courts); M.J.C. Vile, Constitutionalism and the SeParation of POWERS (2d ed. 1998) (describing the separation of powers).

18. See generally Bruce Ackerman, The Rise of World Constitutionalism, 83 VA. L. REV. 771 (1997).

19. Probably the most influential scholar (in the debate about global constitutionalism), who denies the problem of time is Jürgen Habermas. It seems to me that, for him, actors and institutions always have all the time needed to find the most reasonable and universal solution. In his theory time appears only as a "present" which is taken for granted (for example "taking for granted" that the relevant constitutional principles and moral norms are presumptively accepted in the process of constitution making) and as a "future" that is an ideal projection of the citizenry's (well-informed and formed) will. See JÜRGEN HABERMAS, THE CRISIS OF EUROPEAN UNION: A RESPONSE (Ciaran Cronin trans., 2012).

20. See, e.g., George P. Fletcher, OUR Secret Constitution: How Lincoln REDEFINED AMERICAN DEMOCRACY (2001). 
future was frozen inside nation-states, taking for granted a state-divided world. ${ }^{21}$

But after a very short period of time-roughly from the 1950 s to the 1970 s-what was called "globalization" entered the sociopolitical scene and messed up this "stable" sociopolitical configuration. ${ }^{22}$ From the beginning, globalization showed elective affinities with the so-called social-acceleration and with what Luhmann called the "temporalization of complexity." ${ }^{23}$ Temporalization changed everything because "[t]he definitions in relation to persons and to space were in many respects replaced by definitions in relation to time." 24 The problems became not how to "project" an ideal future to orient the present on the basis of a sound and secure past, but how to live in the present without the help of any stable tradition and with the "possibility" of an open and progressive future and, above all, how to project in the future a normative ideal if we are not sure that tomorrow it will be useful and socially acceptable. ${ }^{25}$

On the basis of this theoretical background, I would like to show that changing the form of observation from a spatial to a temporal framework may help in understanding the future of constitutionalism in a different and creative way. To cite but a few of many examples, such shifts could help us to reconsider: (a) the reason so many scholars now prefer to talk about "processes" of constitutionalization instead of constitutions as "structures" (the preference for dynamic instead of static analysis); (b) the growing relevance of courts instead of legislative bodies for processes of global constitutionalization (the preference for short-term decision-making instead of long-term decision-making); (c) the blurring or vanishing of the modern distinction between pouvoir constituant/pouvoir constitué (the preference for the fictitious self-constitution of a "we" before it is actually constituted); (d) the fundamental role of human rights and dignity within the processes of global constitutionalization (the preference for value commitments that do not end in a definitive list of rights); (e) the unexpected and growing function of delayed decision-making as a methodology for maintaining

21. See, e.g., Dieter Grimm, Integration by Constitution, 3 INT'L J. CONST. L. 193 (2005) (recounting numerous examples of constitutions failing and succeeding because of underlying norms and conditions in the ratifying society).

22. See generally THOMAS HYLLAND ERIKSEN, TYRANNY OF THE MOMENT: FAST AND SLOW TIME IN THE INFORMATION AGE (2011).

23. See generally NIKIAS LUHMANN, GESELISCHAFTSSTRUKTUR UND SEMANTIK: STUDIEN ZUR WISSENSSOZIOLOGIE DER MODERNEN GESELLSCHAFT. BAND 2 (1993).

24. NikLas Luhmann, LAW AS a Social SyStem 268-69 (Fatima Kastner et al. eds., Klaus A. Ziegert trans., 2d ed. 2009).

25. See Niklas Luhmann, Are There Still Indispensable Norms in Our Society?, 14 SOZLALE SYSTEME 18, 26 (2008). 
an open future in legal proceedings (the preference for freezing decision-making instead of deciding without knowing the consequences of decisions); and (f) the possible auto-subversion of constitutions through an "extra legal" normative radical subculture (the choice to exit the legal system to serve humanity or other extra-legal values). In my opinion all of these problems have to do with the so-called "temporalization of complexity." Ultimately, introducing temporal analysis into the theory of constitutionalism means dealing with one of the most astonishing possible catastrophes of our social world: social "variety" (the number of possible social operations and their complexity) exceeded the possibilities of stabilization so that evolution could collapse in a self-deconstruction of social subsystems. ${ }^{26}$ In particular, all the arrangements for the stabilization of law-constitutions included-become themselves dynamic and rapidly head toward the variation of law. As Luhmann anticipated, the mechanism for the variation of law becomes circularly supercharged with self-produced conflicts in which the norm stipulates how the conflict is going to be resolved. Legal change becomes normal, and the average period of normative validity decreases, coming closer to a self-contradictory minimum length. This process leads to the loss of the legitimacy and reliability of law in the face of all of the other social subsystems and society as a whole.

Constitutions will remain necessary, but more improbable. Reactions against the culture of constitutionalism are emerging worldwide such as new totalitarian empires (China?), widespread political corruption (the buying and selling of votes, lobbying, economic pressures on the political elites), economization without legal restraint (globalization of mafias), the indifference of global political elites toward the social conditions of excluded people (African and Russian unconstitutional politics), and totalitarianism of the mass media. These phenomena unleash in society new powers and new possible dangers. New opportunities for corruption, subjugation, alienation, and undemocratic political control could emerge without the possibility of a counteracting force with the help of law. The worst landscape is one where the new powers-not only political ones-may operate without any legal control. Of course, one can count on the globalized mass media system always being interested in delivering the "latest news" about scandals and human rights violations, thereby confirming and

26. This means the definitive collapse of the optimistic and progressive evolutionary social thought which reached its peak with the teleonomic theory of Talcott Parsons. See generally UTA GERHARDT, THE SOCIAL THOUGHT OF TALCOTT PARSONS: METHODOLOGY AND AMERICAN ETHOS (2011). See also NikLAS LuHMANN, Die GeseldschafT DER GESELLSCHAFT [THE SOCIETY OF SOCIETY] (1998) (Ger.) (reciting Parson's theory). 
condensing the basic layers of the global legal system. However, no one really knows whether the billions of psychic systems disseminated around the globe will be interested in focusing their attention on such scandals, or if they will be too busy and exhausted by the claims of daily life.

On the other hand, one could dream about a global constitution capable of enforcing the law everywhere. For sure, what we are actually seeing is the widespread use of "symbolic law" to cover up the actions of the powers that be.27 The hope (or illusion) that power could be constituted as a legal order is still present. But if we generalize the idea of power from politics, and re-embed it into new functionally differentiated global spheres, it becomes easy to ask if "the current prominence of the legal system and the dependence of society itself and of most of its functional systems on a functioning legal coding are nothing but a European anomaly, which might well level off with the evolution of global society."28

At the end of the day, it seems that the modern asymmetric relationship between the space of experience and the horizon of expectations is turning upside down. If we conceive the so-called post-modernity as the increasingly "rapid" growth of contingencies (different possible experiences), a new relation comes into being: the thicker the experiences are (positive or not), the more cautious one becomes (because one has to decide cautiously), but also the more open the future (that cannot begin). If this was the case, and for us this means a huge deflation of constitutional values, then "the end of Neuzeit as optimizing progress would have arrived." 29 There will be too many possibilities to manage for a future that never begins because it passes immediately in a past future, or it flies away in a next future. Politics can only react to contingencies and does not have the time to project and organize a "better society"30 - tempus fugit, reality becomes virtuality,

27. E.g., Marcelo Neves, Symbolische Konstitu'tionalisierung [Symbolic ConstituTIONALISM] (1988) (Ger.) (discussing the symbolic function of the texts of constitutions, which feature a lack of legal normative substantiation).

28. The question was asked, obviously, by Niklas Luhmann. LuHMANN, supra note 24, at 490 .

29. KOSELLECK, supra note 3 , at 274.

30. This is the distopic scenario imagined by Emilios Christodoulidis just in this Issue. It is worth noting that Christodoulidis bases his argumentation exactly on the different temporal capacity of political systems (national-states) and economic systems-at the global level-to "irritate" constitutionalism. Economic systems operate in a faster way than political systems. That's why constitutionalisation could be dangerously reduced to a "market capture" without any real connection with democracy. See also Emilios Christodoulidis, Of Boundaries and "Tipping Points": A Response to Gunther Teubner, 20 Soc. \& L. STUD. 238 (2011). 
and the ideal vanishes into the management of a never-ending present. In a nutshell, if modern constitutions could be interpreted as the present future addressed toward the Utopian ideal of "good society," present-day constitutions would tend to defuturize themselves as future-presents and become a legal-political technology of sorts, aimed at steering a temporalized social complexity. This is the only future that may begin.

\section{ESCAPING THE METAPHOROLOGY OF SPACE: ENTERING TEMPORAL ANALYSIS}

The very idea of modern constitutionalism and its legacy is undeniably linked to the emerging features of nation-states. A constitution is a body of metanorms (or the highest-order legal norms and principles) produced by a self-reflective "we" (a well-defined polity) through a political decision that establishes and regulates the exercise of political power and gives a collective and future orientation to the polity. ${ }^{31}$ Only after a long period of "latency," hindered by so-called methodological nationalism, was the idea that constitutions might cross national and international boundaries accepted as a topic of scientific debate. ${ }^{32}$ The single most important phenomenon, which eased the decoupling between constitutions and nation-states, was so-called globalization. The huge explosion of papers and reflections certifies globalization's entry into the scientific and political debate. Nowadays it is almost impossible to add something new without case studies and commentaries.

Globalization introduced at least two innovative phenomena: (1) new and unexpected couplings between law and global, functionally differentiated social spheres (the so-called juridification of social spheres); and (2) the acceleration of time and the emergence of a desynchronized, high-speed society. The new coupling between law and social spheres has been debated worldwide: first through the label of "regulated self-regulations" of different social spheres and then through the concept of "societal or civil constitutionalism." ${ }^{33}$ But even when the

31. See generally Hans Lindahl, Constituent Power and Reflexive Identity: Towards an Ontology of Collective Selfhood, in The PaRadox of Constitutionalism 9 (Martin Loughlin \& Neil Walker eds., 2007) (looking at how collective identity is shaped by political community).

32. See generally Chris THORNHILl, A SOCIOLOGY of CONSTITUTIONS: CONSTITUTiONS and STAte Legitimacy in HistoriCal-Sociological Perspective (2011) (exploring the reasons why modern societies require constitutions and presenting socio-normative analysis of the constitutional preconditions of political legitimacy).

33. The theory of societal constitutionalism is admirably developed by GUNTHER TEUBNER, CONSTITUTIONAL FRAGMENTS: SOCIETAL CONSTTTUTIONALISM AND GLOBALIZATION (2012). 
issue of constitutionalism had almost exceeded the modern boundaries of the state, the whole debate remained directed, and strongly influenced, by a powerful "metaphorology" of space. ${ }^{34}$

Let us look at the work of Gunther Teubner as an exemplary paradigm. From the very beginning, he created a theory oriented by a moral "hidden agenda": to tame the possible uncork of powers, to enchain the Beast(s)! Not only the Leviathan (state power), but all the other emerging "snakes" too. ${ }^{35}$ In Teubner's works, the double function of constitution-constitutive and limitative-deals well with the metaphorology of space. First, someone (the constituent power) has to "constitute" something by drawing a distinction: "this" and "not that"! Then, the constituted power has to be limited, drawing another distinction (legal/illegal), and metacoded by the constitutional-unconstitutional distinction. In other words, first you create an inner space, distinguishing it from the outside; then you reenter the distinction (system/environment) so as to regulate it from within. ${ }^{36}$ The very idea of "drawing a distinction"-the first commandment of system theory, the incipit of the world--uses a spatial metaphor, a slash (/). ${ }^{37}$

Dirk Baecker, for instance, analyzed the problem of power as the reembedding (reentry) of acts of arbitrariness into the frame of arbitration and then developed his theory of forms of arbitration as a sequence going through Nomos (tribal society), privilege (ancient society), reason (modern society), and finally toward the frame that he defines as "regime." 38 Hans Lindhal is working out this sort of theory

34. I use the concept of "metaphorology" in the way it is elaborated by HANS BLUMENBERG, PARAdigMS FOR A METAPHOROLOGY (2010) (arguing for the existence of absolute metaphors that cannot be translated back into conceptual language and which answers the theoretically unanswerable questions whose relevance lies quite simply in the fact that we find them already posed in the ground of our existence).

35. See, e.g., Gunther Teubner, A Constitutional Moment? The Logics of 'Hitting the Bottom', in THE FINANCIAL CRISIS In Constitutional PERSPECTIVE: THE DARK SIDE OF FUnCTIONAL Differentiation 1 (Poul F. Kjaer et al. eds., 2011) (discussing the social effects of the aggressive growth during the financial crisis); Gunther Teubner, Fragmented Foundations: Societal Constitutionalism Beyond the Nation State, in THE TWILIGHT of CONSTITUTIONALISM?, supra note 1, at 327 (describing how constitutionalism should react to an increase in private governance in the transnational sphere).

36. See NIKLAS LUHMANN, INTRODUCTION TO SYSTEMS THEORY (2012).

37. The Laws of Form were elaborated in 1969 by George Spencer Brown and then developed by Niklas Luhmann in his sociological theory. See generally NIKLAS LUHMANN, TheORIES OF Distinction: REDEsCRIBING THE DEscRiPTIONS OF MODERNITY 99 (William Rasch ed., 2002).

38. Dirk Baecker, The Power to Rule the World, in SOzIOLOGISCHE JURISPRUDENZ: FESTSCHRIFT FÜR GUNTHER TEUBNER ZUM 65. GEBURTSTAG [SOCIOLOGICAL JURISPRUDENCE.

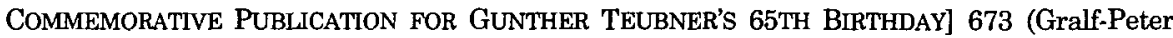
Calliess et al. eds., 2009) (Ger.). 
too: each system (he calls it a "collective," but I call it a "societal subjectivity") includes and excludes its "Other" through its boundaries, and every legal system is recognizable because of its way of building up "ought to do" expectations. This self-constituted legal space (with an inside and an outside) is embedded into another space, a-legality, which is surrounded by an "imaginary space," a Chora (unmarked space), which allows the systems to find their place in the world (i.e. what is not observable as a whole). ${ }^{39}$ And it is precisely here that we can better understand the metaphor of constitution as a "container,"-the idea that law must enchain public powers. ${ }^{40}$

The same spatial metaphors influence the debate about global constitutions, where the goal is to detach constitutions from the spatial boundaries of nation-states. From this point of view, societal constitutionalism is a way to civilize global society or, as Moritz Renner wrote, to "occupy the system(s)." 41 The debate tries to apply the "metaphorology" of space in every possible direction, with the basic problem being the crossing of national borders (by different kinds of law: administrative, private, contractual) and the development of plural legal spheres (lex mercatoria, digital, sports, and artistic). ${ }^{42}$ This represents the invisible frame of all debates. The shadow of the modern self-description of politics (and law) is too strong to be evaded at one stroke: Rechtstaat (the legal state) and then the constitutional statetwo semantics indicating the (imaginary) unity of the legal and political national system-are still mastering and limiting our "sociological imagination."43

Within this powerful spatial frame of reference, however, we risk losing the second condition of possibility for defining something: its identifiability in time! This is the sociological legacy of Talcott Parsons: ${ }^{44}$ if you want to observe something, you have to indicate it (and differentiate it from something else) and localize it in both dimensions of

39. See generally Hans Lindahl, A-Legality: Postnationalism and the Question of Legal Boundaries, 73 MOD. L. REV. 30 (2010) (describing how postnationalism affects a-legality).

40. For the concept of constitutions as containers, see Ulrich K. Preuss, Disconnecting Constitutions from Statehood: Is Global Constitutionalism a Viable Concept?, in THE TWILIGHT OF CONSTITUTIONALISM?, supra note 1 , at 23.

41. See Moritz Renner, Occupy the System! Societal Constitutionalism and Transnational Corporate Accounting, 20 IND. J. GLoBAL LEGAL STUD. 941 (2013).

42. See generally, Paul Schiff Berman, Global Legal Pluralism: A Jurisprudence OF LAW BEYOND BORDERS (2012).

43. E.g., Dieter GRIMM, Die ZuKUnfT DER Verfassung [The Future of The CONSTITUTION] (3d ed. 2002) (Ger.) (discussing how constitutions seem to be losing their validity and how a reformed understanding of constitutions might be able to prevent this development).

44. See generally TALCOTT PARSONS, Social Systems AND THE EVOLUTION OF ACTION THEORY (1977). 
space and time. In other words, you have to identify a system (in an environment). To identify a system is to draw a line in space and time. It is to recall a distinction and to confirm it in time. You need to draw a distinction, but "then" you need to confirm and recall it in the next moment if you want to stress the identity. This is it until further notice, but if you want to change identity you have to take time to cross the previous distinction and pass to the other side! And the process takes time, as every creation does! Constitutions themselves are created as temporalized structures. The famous temporal paradox underlining the distinction between constituent and constituted power (preceded by the equivalent paradox of the social contract, so clearly evident in Hobbes' Leviathan), the phantasmatic presence of the People "before" the people, the problems concerning the arbitrariness of using powers and creating law, and the possibility of amending the not amendable are all features relating to the temporal dimension of constitutions. ${ }^{45}$ Framing the constitution within a temporal dimension means to conceive it as a structural (durable) coupling between politics and law that emerged (at a certain time) to bind social time and to stabilize normative expectation between the two subsystems.

The double function of a constitution is to legalize political power (to limit and enable its utilization in a certain way) and to legitimate the production of law (to evade the problem of arbitrariness). ${ }^{46}$ These two functions bind the "future in the present" with the "present in the future" of a society. For example, anyone can expect that the legislator will decide to enact a statute within a specific legal procedure and in line with constitutional values. If not, the statute will be judged as invalid. The present future of the statute is represented by the will of the parliament formed through, and only by means of, a special proceeding. It is intended to give a certain form to the future of the collectivity: the future present is represented by the normative valid projections enforced by the statute from the moment of its enactment until the day it ceases to be valid. At the same time, everyone can expect that all legal communication will be considered by everyone else as valid law (until further notice). In this sense, a constitution is an effective device to stop the logical regressus ad infinitum, which characterizes the

45. E.g., ERNST-WOLFGANG BÖCKENFÖRDE, STAaT, VERFASSUNG, DEMOKRATIE: STUdIEN ZUR VERFASSUNGSTHEORIE UND ZUM VERFASSUNGSRECHT [STATE, CONSTTTUTION, DEMOCRACY: STUDIES OF CONSTTTUTIONAL THEORY AND LAW] (1991) (Ger.); JAMIN B. RASKIN, OVERRULING DEMOCRACY: THe Supreme CourT vs. THe AMERICAN PEOPle (2003); CASS R. SUnSTEIN, A ConstTTution of MaNy Minds: Why tHe Founding DGCUMENT DoEsn't MEAN What IT MEANT BEFORE (2009); Jon Elster, Arguing and Bargaining in Two Constituents Assemblies, 2 J. CONST. L. 345 (2000).

46. See generally Luhmann, supra note 14; TEUBNER, supra note 33. 
foundations of valid law and the legitimacy of political power. ${ }^{47}$ It is worth noting that regressus is a problem of time: you do not have enough time to follow the stream until the end.

From a temporal point of view, a constitution is a legal and political device geared toward stabilizing normative expectations, especially with the use of so-called constitutive rules: rules (expectations) about how to rule. The temporal dimension of constitutions is relevant not only because they play the role of a stop-rule concerning the foundation of law (what or who legitimates the constitution: God, the People, law itself, stakeholders, the spirit of the time, nothing), but "above all" (another spatial metaphor) because the function of law (and of constitution as "basic law") is to bind time and not, as many theories say, to integrate society.

A second way to introduce time horizons in our reflections is to try to understand the impact of the so-called temporalization of law on the very idea and practice of constitutions and constitutionalism. ${ }^{48}$ From this point of view, I want to underline the contradictions between the constitution as basic law-the law that cannot be changed or that can be changed only through very special and "slow" proceedings-and the "hurry" resulting from the need to change the law in the face of environmental irritations. $49 \mathrm{My}$ suggestion is that focusing on time might help us in our thinking about the future of constitutions, in the sense of which (cognitive and normative) expectancies we could have regarding their developments up to this decisive question: In the age of the temporalization of law, could constitutions continue to function as a special kind of "immune system" of society, or could we expect the emergence/emergency of a sort of a global immune-deficiency? ${ }^{50}$ Will societal constitutions continue to operate on the basis of their constitutional codes (rules for conflicts capable of regulating the collisions between the differentiated organization of "collective" powers and between those powers and their environments) and react against the environmental irritations, or will the nontractable hyper velocity of

47. See, e.g., Giorgio Agamben, State of ExcePTion (Kevin Attell trans., 2005); Jacques Derrida, Force de loi: Le "fondement mystique de l'autorité" [Force of Law: The "Mystical Foundation of Authority'], 11 CARDOzo L. REv. 920 (1990).

48. I found similar insights in Neil Walker, Out of Place and Out of Time: Law's Fading Co-ordinates, 14 EDINBURGH L. REV. 13 (2010), but he still insists on a metaphor of space: "uncharted" law. See also David STRAuss, ThE LIVING Constitu'tion (2010).

49. This was the traditional idea of the Constitutions as the basic Law. Recall that Locke argued that the fundamental Constitutions of Carolina should remain the sacred and unalterable form and rule of government forever. This preference for an unchanging body of constitutional law long exerted a strong influence on the mainstream of liberal democratic constitutionalism and a clear veto to amendment procedures.

50. LUHMANN, supra note 24 , at $475-77$. 
changing rules and laws transform the basic law itself into a danger for the social system? Will constitutions react against themselves, unleashing self-destructive immune-deficiency syndrome across society? To cite one example: will the European Union avoid constitutionalizing itself in a better way (or at all) because of the huge irritations coming from the economic systems? Will the idea of constitutionalizing the balanced-budget be a viable one? And further, given the necessity of changing laws as soon as possible, will constitutions transform themselves into empty boxes for value commitments-that is pure symbolic politics for a Utopian present future so abstract as to serve nothing? These are only some of the questions an observer could ask, but only if he is able to shift the focus of his attention from the spatial analysis of constitutions to their temporal analysis.

\section{TIME IS ON MY SIDE (AND RIGHTS TOO!): THE TIME-BINDING FUNCTION OF LAW}

In order to focus on the topic in this section, we need to start afresh by reflecting on the basic function of law. Sociologists usually start by affirming that the function of law is to "integrate" society or to solve (to "hide" or "conceal," in the critical version) its conflicts. ${ }^{51}$ Crucial as they may be, however, these functions do not represent the function that law operates for society as a whole. It is worth noting that according to these theories, constitutions are devices conceived as basic higher laws needed to integrate-symbolically or instrumentally-a national society. ${ }^{52}$ From this point of view, a constitution tends to become a sort of symbolic "ID" of a nation, and its legal relevance practically vanishes. Constitutional actors are so petrified that the constitution's present future is expected to control and reproduce its future presents that it operates as a negative feedback device addressed to maintain the identity of the system (morphostasis). ${ }^{53}$ The right value is "latent pattern maintenance," and amendments are introduced only when very special reasons can be found to do so. At the same time, the idea that constitutions could exceed national borders is a "taboo" because this is

51. See, as the champion of this idea and deriving from the work of Emile Durkheim and Talcott Parsons, JURGEN HABERMAS, BETWEEN FACTS AND NORMS (1996).

52. See generally Geoffrey BRENNAN \& JAMES M. BuCHANAN, THE REASON OF RULeS: Constitutional Political ECONOMY (1985); JÜRgEN HABERMAS, BETWEen FACTS AND NoRMS: CONTRIBUTIONS TO A DisCourSe ThEORY OF LAW AND DEMOCRACY (1998); Dieter Grimm, The Constitution in the Process of Denationalization, 12 CONSTELLATIONS 447 (2005); Neil Walker, Beyond Boundary Disputes and Basic Grids: Mapping the Global Disorder of Normative Orders, 6 INT'L J. Const. L. 373 (2008).

53. See WALTER BUCKLEY, SOCIOLOGY AND MODERN SYSTEM THEORY (1967). 
immediately perceived as a "violation" of identity or dissolution of the political "body."

We need to change this analytical frame to go a step further, and in doing so we can count on Niklas Luhmann's analysis. Luhmann conceives law as a social "language" performing the function of maintaining (stabilizing) normative expectations in the face of (ongoing) disappointments: law binds time (Zeitbindung). ${ }^{54}$ The functions of law are not represented by its social performance. For example, in regulating human behavior or resolving dispute, society has developed many functional equivalents to accomplish these functions. Law deals with communicating expectations so as to make sure they are accepted in further communications. Therefore, law fails to carry out its function only when the expectations it communicates cease to be normative. If people look at you as a fool when you claim your right not to be beaten up by a policeman, then law is not in action (or there is a emergency power in action). Expectations are the fabric of society. Nobody can do anything without this enduring time horizon. Expectations are condensed and confirmed in social structures that normally are coupled with consciences. ${ }^{55}$ Without social expectations it is impossible to solve the problem of double contingency: in other words, it is impossible to have a society, but only incoherent events. ${ }^{56}$

Normative expectations link the present (the only time at our disposal) with projections of the future, which are expectations as to what will be socially approved in the future. The problem is pervasive and inescapable: everything happens only in the present! Systems do whatever they do for the first and the last time, as an event, all the time. Events have no duration and cannot be changed, only memorized or forgotten. Systems exist only at the point in time in which they operate: they are forced to assume an uncontrollable world that exists simultaneously at that point of time. The only way to extend time (that is, to "gain" time for operating with ease) is to fix the "present" as a distinction between "past" and "future." This fix allows systems to distinguish themselves through their own operations linking their present situation with past and future situations. ${ }^{57}$ Only in the present can systems consider the past as something that cannot be changed and

54. See LUHMANN, supra note 24 , at $142-72$.

55. This is not a fact to be taken for granted.

56. See NikLas LuHManN, Social Systems 103-36 (John Bednarz, Jr. trans., 1995) (explaining the fundamental relevance of the solution to "double contingency" for generating social systems).

57. See generally Elena Esposito, The Future of Futures: THE Time of MONEY IN FINANCING AND SOCIETY (2011) (introducing the systemic theory of time, especially in connection with economics). 
the future as something that can be changed. Only with an open future can systems project, make selections, control their internal states, and try to influence the surrounding environment. Only within time can a system decide, and decisions are special ways of dealing with time, reducing the oppressive uncertainty of the future. ${ }^{58}$

Every decision exerts its influence on future presents, i.e. on the conditions of possibility of the system itself. That is the reason why every decision should evaluate its consequences for the future and develop some kind of (presumed) rationality. ${ }^{59}$ On this "ephemeral" basis nothing can easily be connected with anything else. To endure, systems need to create temporal structures: expectations of expectations (reflective expectations). This creation explains the system's self-referentiality in regard to its temporal dimension: it construes its present as the past of its future present, that is, as a condensed rule for future decisions. A system has to connect its "futures in the present" (what it can expect now for its future) with the "presents in the future" (what the system cannot control) in a meaningful way. The peculiarity of law is not only to be a temporal structure, but also to make it possible to know which expectations will meet with social approval and which will not. Luhmann calls these kinds of expectancies "normative" to distinguish them from "cognitive" expectations.60 When normative expectations are coded using the legal-illegal dichotomy, society begins to build a legal subsystem and distinguish it from its environment. The closure of the legal system is needed to reduce complexity and is based on a fictive self-representation that gives unity to a difference (between law and not law). ${ }^{61}$

To stabilize a subsystem of law, some internal and external conditions need to be met. Internally, it is necessary to develop organizations capable of deciding what the law is; externally, it is necessary to manage, politically and ethically, dissent and conflicts between law and its environment. For my purposes, it is necessary only to introduce the "sancta sanctorum" of the system of law: legal validity. Validity is the symbol for the connection of legal communications, its internal "connecting value."62 From this point of view, validity is duration, the possibility to maintain and to secure ongoing legal

58. See generally, HERBERT A. SimON, MOdELS OF BOUNDED RATIONALITY, Vol. 1, 2, 3 (1984/1987); JAMES C. MARCH \& HERBERT A. SIMON, ORGANIZATIONS (1993).

59. See generally NIKLAS LUHMANN, ORGANISATION UND ENTSCHEDUNG [ORGANIZATION AND DECISION] (2000) (Ger.) (demonstrating the internal and logical connection between organization, time, risk, and decision).

60. LUHMANN, supra note 24 , at 357-80.

61. See generally GUNTHER TEUBNER, AUTOPOIETIC LAW: A NEW APPROACH TO LAW AND SOCIETY (1987).

62. LUHMANN, supra note 24 , at 122. 
communication. In the "meantime," nothing changes, and everyone can continue to operate without fearing about the next moment. Validity is the "symbol for the dynamic stability of the system, which is expressed in backward and forward references to the past and the future."63 Without this entangled structuring of time, society cannot elaborate law. Law can exist as a system of communication only if its symbol can be circulated, expected, and recognized in society.

It is time to go a step further. The system of law is a closed system because everything that counts within it is mediated by its code (legal/illegal). ${ }^{64}$ At the same time, it is an open system continuously irritated by its environment. And the modality of irritation depends on the form of societal differentiation that influences the degree of social complexity. This means that the relationship between the subsystem of law and society can change (and indeed does). It is precisely this relationship that makes the future of constitutions more challenging. In the modern world, the awareness of complexity and the acceleration of structural changes in nearly all social domains arise and rule out the claim that the problems of the world can be worked out logically or theoretically. ${ }^{65}$ Nobody has the time or the knowledge to work out all of the problems of the world in that manner. This is the paradoxical, risky situation of the so-called knowledge society: the more you lack the knowledge needed to solve problems, the more you have to decide so you can reduce uncertainties.

Society shifts from a generalized "normative" style to a cognitive style to deal with uncertainties. ${ }^{66}$ If you are disappointed, you must learn that you lack support from other people in maintaining your expectations: you become simple-minded, a traditionalist, or someone embedded in cultural relics. On the contrary, you can act resolutely if the law is on your side. The paradox, however, is that now legality is under siege too:

Against better knowledge, it must be pretended that there was something which is reliable, or which-at least-justified a certain course of action. . . . For, if the pressure for action cuts the search for knowledge short, no guarantee can be demanded for the enduring validity

63. LUHMANN, supra note 24 , at 129 .

64. For the systemic theory of law, see GUNTHER TEUBNER, LAW AS AN AUTOPOIETIC SYSTEM (1993).

65. See generally NiKlas LUHMANN, OBSERVATIONS ON MODERNITY (1998).

66. See generally Nico STEHR, KNOWLEDGE Societies (1994); HELMUT WiLlKE, SMART GOVERNANCE: GOVERNING THE GLOBAL KNOWLEDGE SOCIETY (2007). 
of a decision, and options must be kept open for new doubts, better insights, and a change in the rules. ${ }^{67}$

Of course, there are many functional equivalents for certainty: religious fundamentalism, economic provisions, political ideologies, the mass media's illusion of control, and scientific publications. These structures, however, do not produce normative expectations, that is, something that is normatively expected by others too.

What happens when global society starts to accelerate and prefer cognitive expectations, that is, to sensitize expectations to learning? Simply, that the old idea of society as a cybernetic machine-and that of the legal system as the inner regulatory mechanism serving the adaptation of society to its environment-comes crashing down. ${ }^{68}$ Within globalization and high-speed society, the function of law seems to be declining and vanishing. The evolution of society leads to the morphogenesis of systems and toward the normalization of improbabilities. ${ }^{69}$ Above all, this means that the symbols of legal validity, and among them the constitution as the basic law, begin to dissociate from any original beginning and from any external reference..$^{70}$ Law is law (and nothing else), and it must change. New laws replace old ones, and even sharp temporal inconsistencies should not be seen as unjust per se. Law is valid only until further notice.

Temporalization is increased when legal norms come equipped with assumptions about the ever-changing reality. This is when the legal system begins to reincorporate environmental reality into itself. Norms are cognitively sensitized, equipped with "assumptions of reality," and, of course, considered to be errors in the legal system. ${ }^{71}$ The legal system might be pushed to a final paradox: taking for granted the "facticity" of law as it is found because of the huge effort to reform it. In the end, we could find the reintroduction of arbitrariness into the legal system, which is a sort of law without any motivational force. A law is capable of linking legal communications only for a while and without any social legitimacy. This kind of inclusion is very risky: the legal system starts to produce risks from within and needs to limit itself in front of intractable complexity.

In summary, in the age of the acceleration of time and of temporalization of social complexity: (1) every temporal extension of

67. LUHMANN, supra note 24 , at 286.

68. For this distopic landscape, see $i d$. at 469.

69. See generally William E. Scheuerman, Liberal Democracy and the Soctal ACCELERATION OF TIME (2004).

70. See TEUBNER, supra note 61.

71. LUHMANN, supra note 24 , at 464-90. 
expectations puts a burden on those who will suffer if their future becomes restrained, that is, those who have to obey the law without being included in the procedure of its creation; (2) legal validity, the invariable and secure point of departure for the circulation of legal communication, begins to change and means that what is deemed valid is valid until it is changed (and nobody knows when this will happen); and (3) the estimation of consequences as a principle for decisionmaking pushes the validity of law into the future. However, nobody has the information needed to decide, and nobody knows what will happen after the decision is made. The present future of law is irreparably disjointed with regard to its future presents. The future of law is squeezed between Utopian and normative ideals of law and a mere technology of lawmaking. The futurization and defuturization of law and the inflation and deflation of law are simultaneously "present."72 The horizon of law, expected to link sky (values, ideals, and visions) and earth (facts, realities, and realism), is not approachable.

\section{LAW IN THE AGE OF SOCIAL ACCELERATION: From SECURITY AND STABILITY TO RISKS AND FlEXIBILITY, FROM INTERPRETATION TO CREATIVITY, From PaRliamentaRY LEgisLation to COURTS AND GOVERNMENTS}

We can observe the consequences of high-speed society on law from many different points of view. In a nutshell, the debate identifies a new dramatic dilemma: accelerating lawmaking and risking the loss of democratic procedures (legality) or maintaining long and slow democratic procedures and losing the capacity to make law (legitimacy). ${ }^{73}$ New clashes among the values of change versus permanence, adaptation versus tradition, flexibility versus permanence, and frozen constitutions versus living constitutions arise. I will discuss four crucial problems.

\section{A. From Legal Security, Stability, and Clarity to Risk, Flexibility, and Opaqueness}

We have seen that global society is increasingly sensitized by cognitive styles. In the design of both system theory and society, the principle of risk (and correspondingly of new dangers) replaces the 141.

72. For the concepts of futurization and defuturization, see Luhmann, supra note 9, at

73. See SCHEUERMAN, supra note 69. 
principle of adaptation. ${ }^{74}$ This means that decisions are expected anytime and everywhere because they are the ultimate mechanism for absorbing uncertainties. If you cannot foresee the future presents, it is better to decide immediately, hoping that your decision changes the situation. And if you choose, you take a risk. The result is that only society can destroy itself with its decisions (or deciding not to decide); it has to be responsible for its solutions. Society starts to experience an uncomfortable sense of instability. But exactly for the same reason, normative expectations and their stabilization retain and increase their importance. Law remains concerned with the contra-factual stabilization of the future's projections. But, as Luhmann affirms,

there is an intensification of the problem that can be defined as the distinction between the present's future and the future's present. Law cannot be stable over time in the sense that what is valid once is valid forever. If one wants to rely on law, one can count on support against resistance and disappointments but one cannot expect that the law will not change. ${ }^{75}$

Therefore, law has to pay attention to law's own risk. And it must do it mainly without the help of politics.

With law, society must secure its future in the present, but cannot say anything about its presents in the future since law must make do without a certain future. Securing the present through legislation, for instance, means to supply society with relatively unchanging and stable norms that possess a reasonable chance to endure for a lengthy period of time. Stable norms allow individuals to plan and coordinate their activity and ensure that societal actors operate in a predictable legal environment. In a seminal work, William E. Scheuerman demonstrated that "like rational maps and clocks, the modern rule of law implicitly rested on the aspiration to render both time and place rationally manageable."76 In modern law, every rule builds on predictions about the future drawn from past and present experiences. Forcing the future into the law was not problematic because traditional forms of rulemaking and adjudication rested on a marked orientation to the past. With globalization, this traditional alliance between the rule of law (based on a system of clear, general, stable, prospective, public, and

74. LUHMANN, supra note 24 , at 472 .

75. Id. at 471.

76. SCHEUERMAN, supra note 69 , at 158. 
private norms) and societal processes, a Weberian and "modernistic" topic for sure, collapses.

According to Scheuerman, globalization flourishes where such legal culture declines. Because of its preference for porous, open-ended, and soft law, computerized currency trading and its hypervelocity, which is not manageable by normal human beings, is a good example of the vanishing of the liberal rule of law model. Not even the modern codification of commercial law is useful for high-speed society. For instance, in litigation proceedings, the new value is not in assigning guilt to one party in reference to a past act, but the value is in a quick compromise or agreement emphasizing positive lessons to be learned for the sake of maintaining cordial ties in the future. ${ }^{77}$ What is remarkable, here, is the temporalization of the validity of law, since continuity with the past may appear to be an impediment to successful economic action. Scheuerman sums up these argumentations with a sharp statement:

Traditional forms of lawmaking are rapidly rendered out-of-date given the dynamic character of social and economic change, and the half-life of formal and even more flexible 'substantive' legal norms appears to be experiencing a dramatic decline: in the age of speed 'law will be easily trapped in the dilemma: either to remain static and be ignored, or to keep up with social dynamics and to be devalued as a normative reference. ${ }^{78}$

\section{B. From the Enactment of Law Toward Creativity and the Tyranny of Presumptive Consequences}

The acceleration of society leads to another basic change in the very foundation of law. The dilemma here is between deciding to weigh the consequences of decisions without being obliged to implement the law in any case or guaranteeing long procedures and proceedings so that the decisions can be delayed. The legal system turns to the prognosis of consequences and the justification of decisions by reference to their consequences, without being able to doctrinally deal with the problems that arise. In other words, "doctrinal resources are depleted and replaced with the flexible, if not empty, paradigm of the weighing up of interests or balancing of values." 79 This new legal culture simultaneously enables and constrains the system of law. This legal

77. See LUHMANN, supra note 65.

78. Id. at 213-14.

79. LUHMANN, supra note 24 , at 455. 
culture enables the system to self-reproduce through decision-making, while also constraining the system because

[t]he seemingly firm order of legal propositions (and its traditional form of consistency-test) is guided by fluid, provisional decision-making on the basis of an appreciation of values, and thus by unstable guides for the relatively stable system. This means, using the terminology introduced above, that the variety of the system increases and that the maintenance of redundancy becomes a problem. ${ }^{80}$

This new legal culture results in what we can call the normal chaos of law (not of love!), and it is especially spreading in the field of legislation and the judiciary. It is worth noting that the emergence of those new criteria of decision-making, the reference to "presumptive consequences," is driven exactly by the effort to project in the "present future" the "future presents." Luhmann considers this astonishing effort as the ultimate attempt to give form to legal concepts, even if it is through social processes that tend to conflate innovation and variation in the absence of stabilization: "If there are ever to be legal concepts which are socially adequate, they will have to be found through a testing and re-testing of solutions to establish potential eigenvalues of the legal system in modern society." 81 We can call it abstinence from clear and sound principles. That is why law is looking for self-produced eigenvalues. Inside the system of law, this abstinence is not welcomed. Making decisions about hard cases, for example, where existing and valid legal norms do not lead to unequivocal decisions, is a paradoxical activity. One must decide by relying on recorded "precedents" (abstracted rules for conflicts), but that is impossible. Here, judges have to decide without a valid rule of decision-making and have to leave it contested. They can only "oscillate" between the values of the legal/illegal code. That is why the institutions of legal force or "objective responsibility" emerge, trying to stop the circular regression of legal argumentations. And, finally, that is why, if the court cannot find a law to enforce, it must create one. Courts have abandoned the retrospective temporal perspective favored by traditional jurisprudence, and as Scheuerman attests, the tendency toward creative judicial activity and interpretation is now nearly universal.

80. Id. at 411.

81. Id. at 473 . 


\section{From the Modern Separation of Powers and Temporal Division of Labor to the Emergence of a New Temporal Hierarchy}

The separation of powers (institutional units, body of personnel, and functional activities), probably the most important aspect of constitutionalism, is based on clear assumptions about temporality. Liberal democrats accepted the idea that legislation refers to the making of new laws and statutes; execution means enacting those laws, and judicial power entails declaring what is right in the event of controversy. Scheuerman underlines this latent temporal subtext, indicating that legislation is conceived as a prospective and future-oriented activity; "[J]udicial activity is fundamentally retrospective, or past-oriented; and the executive is contemporaneous or present-oriented." 82 In a nutshell, the modern constitutional division of powers reproduces inside its institutions the temporal division of past, present, and future. Another way to understand this division is to connect the value of deliberation with legislative powers and parliaments and those of action with executive powers. In the modern liberal tradition, legislation and lawmaking are connected with the idea of a slow, reasonable, rational, inclusive, open, transparent, and competent discussion. Parliaments are the places where the value of political representation is enacted. And discussing before deciding takes a lot of time. Legislation is a very time-consuming activity. What does it mean for an accelerated society? From a modern point of view, it means that deliberative procedures have to adapt to the new temporal situation, trying to improve their modern ideals. Contemporary theorists of deliberative or participative democracy picture political debate as requiring pompous normative ideals of equality, reciprocity, openness, perfect information, and more inclusiveness than previous forms of democracy. ${ }^{83} \mathrm{~A}$ huge part of the current debate is devoted to looking for new technologies capable of improving popular deliberation and direct citizen lawmaking and proposing universal distribution of these new time-saving technologies. ${ }^{84}$ Not to say about the huge

82. SCHEUERMAN, supra note 69 , at 29 .

83. See Bob Jessop, The Spatiotemporal Dynamics of Globalizing Capital and Their Impact on State Power and Democracy, in HiGH-SPEED SOCIETY: SOCIAL ACCELERATION, POWER, AND MODERNITY, supra note 2, at 135.

84. The literature about democracy, political participation, new methods of political decision, and the impact of new technologies is enormous. Only as introduction, see JOHN O. McGinnis, accelerating Democracy: Transforming Governance Through Technology (2012); Digital Citizenship: The InTERnet, Society, and Participation (Karen Mossberger, Caroline J. Tolbert \& Ramona S. McNeal eds., 2007); IAN BUDGE, THE New Challenge of Direct Democracy (1996); Digital DemOCRACY and THE IMPACT OF Technology on Governance and Politics: New Globalized PraCtices (Christina M. 
questions concerning how technologies will affect law in the near future. 85

But all these attempts at improving the deliberation process lead directly to a new dilemma: whether to increase participation and time-consuming procedures or to delegate regulatory authority, thus speeding up deliberation but losing representativeness. The same dilemma concerns the ideal of an active citizenship-well-informed, politically committed, interested in civic participation, and competent in public debates-and citizens dimly interested, "bowling alone," and connected with the public from time to time. ${ }^{86}$ Many scholars talk about political apathy, the loss of political vision and narrative, civic disorientation or anomia, intolerance towards time-consuming political debates, and a deep "political deterioration" in the quality of citizenship. It is here that the paradox of political time, as explained by Hartmut Rosa, can be understood. 87 The contraction of the temporal horizon in high-speed society increases the scarcity of time resources, and, because of the contraction of the present, the horizon of rational calculability decreases, the time-span for decisions decreases, and the number of necessary decisions increases, thus again reducing the available time per decision. This means that the temporal range of the effects of decisions increases; the demand for collective regulation in consequence of growing contingencies increases; and the political and cultural common ground for decision-making shrinks because of the increase of cultural pluralism (as the works of William E. Connolly and James Tully demonstrate). ${ }^{88}$ The effect of these two parallel processes is the transfer of decision-making from parliaments and other modern institutions to faster systems. 89 The time of a parliamentary democracy cannot begin, for it is projected toward the untouchable horizon of a utopian participatory democracy or exploited as a technical device for

Akrivopoulou \& Nicolaos Garipidis eds., 2013); CONSTITUTION 3.0: FREEDOM AND Technological Change (Jeffrey Rosen \& Benjamin Wittes eds., 2013) (discussing the consequences of new technologies on constitutional values); see also Giulia Dessi, The Icelandic Constitutional Experiment, OPEN DEMOCRACY (Oct. 23, 2012), http://www.opendemocracy.net/giulia-dessi/icelandic-constitutional-experiment.

85. The Law of Future and THE FUTURE OF LaW: Volume II (Sam Muller, Stavros Zouridis, Morly Feishman \& Laura Kistemaker, eds., 2012).

86. See William E. Scheuerman, Citizenship and Speed, in HIGH-SpEED SOCIETY: SoCIAL ACCELERATION, POWER, AND MODERNTTY, supra note 2, at 287.

87. See Alienation, supra note 5.

88. William E. Connolly, Speed, Concentric Cultures, and Cosmopolitanism, in HIGH-SPEED SOCIETY: SOCIAL ACCELERATION, POWER, AND MODERNITY, supra note 2, at 261; TULLY, supra note 12.

89. Beginning with CARL SCHMITT, The CRISIS of PARLIAMENTARY DEMOCRACY (1988) to end with all the critics of the malfunctioning and the democratic illegitimacy (or weakness) of the European Parliament. 
"motorized" legislature as Carl Schmitt predicted in the 1950s.90 The two fastest systems with the capacity to compensate for the ineptitude of legislatures could be the executive and the judicial branches. The former had its time, at least at the national level, in the 1980s, sustained by the (very simple) hopes for their political consistency. Decrees and orders were the solutions to every problem, and presidential and semi-presidential regimes were the best institutional devices. The fields of intervention were foreign political crises, sudden economic downturns, and civil disorder. ${ }^{91}$ The traditional metaphor of a unitary executive, however, proved to be wrong because of the complexity of any administrative action, a divided state, and the ever growing and chaotic composition of executive bodies.

The real winner in the debate between Schmitt and Frank was most likely Jerome Frank and his powerful idea of the judicial answer to social acceleration. ${ }^{2}$ Courts (first of all constitutional courts), arbitration bodies, and their accelerated kin are identified with a reduced emphasis on legal precedents and preexisting standing rules. For instance, the procedures of the many international business arbitration panels emphasize speed, the abandonment of time-consuming technicalities, and the formalities of traditional adjudications. In a sense, we can talk about a double movement concerning the temporal division of labor in traditional liberal democratic institutions. The first movement is from the modern centrality of legislative power toward the accelerating decision-making procedures of government-like institutions. In high-speed society, general legislative debate is shortened or sped up. Deliberation is compressed in small collegial bodies or committees in which "expert" opinions may be accelerated. ${ }^{93}$ It is evident that the construction of political consensus, too, will change greatly within this new frame. The second temporal shift is from the centrality of the "dispatching" and "energetic" executives toward a new centrality of courts: "Like parliament, the judiciary might imitate the executive and thereby streamline its tempo in accordance with social acceleration but only at the cost of abandoning its special normative and institutional attributes." 94 By now, it is quite evident that high-speed society drives

90. Carl Schmitt, The Motorized Legislator, in HIGH-SPEED SOCIETY: SOCIAL ACCELERATION, POWER, AND MODERNITY, supra note 2, at 65.

91. William E. Scheuerman, Emergency Powers, 2 ANN. REv. L. \& Soc. SCI. 257, 264 (2006).

92. See Jerome Frank, Law ANd The Modern Mind (1930).

93. See generally and only for the EU, 21ST CENTURY Comitology: IMPLEMENTing COMMITTEES IN THE ENLARGED EUROPEAN UNION (Thomas Christiansen, Johanna Miriam Oettel \& Beatrice Vaccari eds., 2009).

94. Scheuerman, supra note 69 , at 58. 
us toward an accelerated normative culture. What does this culture mean for the very idea of constitution and constitutionalism?

\section{CONSTITUTIONS AS StRUCTURAL COUPLINGS AND STRUCTURAL COUPLINGS AS TEMPORAL COUPLINGS}

It is time to explain the emergence of modern constitutions as a temporal problem. Within the framework of systemic theory, it is necessary to distinguish two different but interrelated subjects: (1) the difference between operative and structural couplings; and (2) the difference between synchronicity and synchronization. Given the operative closure of autopoietic systems, it is necessary to distinguish between "operative" and "structural" couplings. Operative couplings are twofold; on the one hand, they refer to the coupling of operations within operations, that is, autopoiesis, and, on the other hand, operative couplings concern the coupling between systemic operations and those operations that systems attribute to the environment. Both are only possible in the present, event after event: they emerge because of the synchronicity between systems and environments. ${ }^{95}$ These connections are relevant but too volatile to allow the establishment of a durable, stable relationship. From an evolutionary point of view, however, certain ongoing relationships between social subsystems occur with the emergence of "structural" couplings. Here, structural means "endowed with a duration and stability." A single operation can be attributed simultaneously, but with a different meaning, to more than one subsystem. Enduring couplings simultaneously reduce and facilitate the influences of the environment (i.e. other subsystems) on the system. Reduce means both limit and enable: reduction and limitation are necessary conditions for enabling. ${ }^{96}$

If you conceive a constitution as a limitation of powers (economic, political, or scientific), you are faced with a double paradox. Constitutions protect citizens, entitling them with individual rights and enabling them in a positive way: these enabling rights are useful only if they are, at the same time, partially disabled or limited. ${ }^{97}$ Natural "freedom and equality," the basic rights needed for modern political inclusion, must be limited, as occurred in the early contractualist legacy and in the famous "right of resistance." These limitations (negative constitutionalism) enable freedom and equality values (positive constitutionalism) and, through individual rights, enforce these values

95. For the theory of structural coupling, see NIKLAS LUHMANN, THEORY OF SOCIETY, VOLUME 1 (2012).

96. LUHMANN, supra note 24 , at $381-423$ (discussing structural couplings).

97. See THORNHILL, supra note 32. 
within society. 98 In a sense, constitutions mold the societal political sphere by depoliticizing it and giving shape to the foundation of law by delegalizing it. The reciprocity between disablements and enablements and limitations and constitutions led modern Western society toward the search for a "single formula" capable of symbolically explaining the unity of society. ${ }^{99}$

The paradoxes of couplings were first superseded by the idea of the social contract and then by the establishment of the rule of law. 100 Modern territorial nation-states selected their mission as the unification of valid law and legitimate public powers within their territorial boundaries. A constitution

functions as a schema which makes it possible to define two reverse perspectives as a unity and to celebrate it as an achievement of civilization: the juridical shackling of political force and the political exploitation of law. . . . Accordingly, there is a juridical framing of state-issued decisions and finally a juridical concept of the state as a point of reference for all decisions that are supposed to be collectively binding from the perspective of the political system. Seen from the perspective of the legal system, decisions have this effect only if they are lawful and not in contravention to law. ${ }^{101}$

Constitutions work as a taken-for-granted and lasting framework for enabling legitimate and lawful powers, i.e. self-limited public powers. That is why, as long as there was no constitution in the modern sense of the term, the problem of resistance remained the core problem of the modern state at the point where the law conflicts with politics. As Luhmann emphasized, "[h]ere lies the hidden motif of all theories built on the unity of politics and law. In other words, the difference between the legal system and the political system can be understood, under the prevailing premises, as legitimate resistance to the political exercise of power." 102 It is worth noting that before the emergence of constitutions and the clear distinction between politics and law, the right of

98. For the distinction between negative/positive constitutionalism and enabling/disabling constitutionalism, see generally HoLMES, supra note 17.

99. See Chris Thornhill, Niklas Luhmann and the Sociology of the Constitution, $10 \mathrm{~J}$. ClassiCAL SoC. 315, 321 (2010) (arguing that the sociology of constitutions has been an important, but submerged, area of sociological inquiry).

100. LUHMANN, supra note 24 , at $423-63$.

101. Id. at 368-69 (emphasis removed).

102. Id. at 361 . 
resistance could only be understood as a danger for the unity of society because every individual might intervene in politics, destroying peace. ${ }^{103}$

Constitutions contribute to the process of functional differentiation by enabling social systems to produce more complexity in the circulation of powers and in their legal securitization via rights. Complexity is viable only if channeled into structures of expectations so that one can expect to link one's operations with other socially expected operations. This does not mean that constitutions can unify politics and law at one stroke. Politics is not an ongoing interpretation and enactment of a legally fixed constitution, and the legal system is not continuously committed to the implementation of political programs and plans. Politics and the legal system remain different subsystems with idiosyncratic time horizons, and it becomes increasingly improbable that the latter could find a simple synchronization.

The operative time frames of subsystems are autonomous. Law has its time frames (procedural time limits, limitations period, appeals, and exchanges of legal correspondence) that do not fit with the times of politics (parliamentary session, consultations period, public announcement, political campaign, construction of public opinion, not to mention the activities of political parties). Even if from an external point of view, the enactment of legislation can be seen as an event pertaining to both the legal and the political system, each subsystem treats legislation its own way. Politics will work legislation out through preparative communications, political negotiations, political exchanges, consultations, debates, and votes, which normally are not even registered by the legal system unless the legal system needs these measures to reconstruct the intentions of politicians. Social subsystems grow older together, but they process their own temporal contexts in different ways. Time passes for all, but each subsystem articulates time for its own purposes: system and environment irritate themselves on the basis of the specific system's time frame. Each system registers the irritations by coding them into a historic time, a memory structure, or an identity. The irritating event is only possible if it is projected into the structures of expectations, which create the history of the system. ${ }^{104} \mathrm{It}$ is only with the help of these immunity structures that the system can try to find quick solutions to the irritations and prepare for what may happen.

103. For this problem, see QUENTIN SKINNER, THE Foundations of MODERn POLITICAL Thought, Vol. 2: THE AgE OF REFoRMation (1978).

104. Very useful here is Histories of Nations: How Their IDENTITIES WERE Forged (Peter Furtado ed., 2013). 
Coupled systems react to reciprocal irritations at different speeds. Their speed depends on their structures and, therefore, on their histories and identities. Structural coupling guarantees only the synchronicity of the system and the environment for a single given event, but not synchronization. Here, synchronicity means that the specific corridors linking politics and law were constructed to permit mutual irritations and that corridors can endure for sometime: everyone can expect that politics is legalized and that law is an instrument for politics. In other words, law "provides immunity structures, which prevent ongoing disappointment from resulting in the annulment of the structures."105 Restricting the reciprocal influence of law and politics means simultaneously increasing their operative possibilities in the framework of their coupling. By limiting contacts, more possibilities are created for the legal system to register political decisions in a legal form and for the political system to use the law for the implementation and enactment of its own policies. Since then, a "constitution has been understood as [a] positive statute law, which constitutes positive law itself and through that regulates how political power[s] can be organized and implemented in a legal form with legally mandated restrictions."106

\section{Constitutions as ATTEMPTS TO SYNCHRONIZE POLITICS AND LAW: THE PROBLEM OF THE TEMPORAL IDENTITY OF CONSTITUTIONS}

Modern constitutions (e.g. the American and French ones) were and are presented in history as revolutionary and as "the accelerated concentration of all possible histories." 107 This "beginning" (its empirical and historical accuracy notwithstanding) put them in a strange temporal landscape. In the first instance, modern constitutions were presented against the old times and the old political and legal structure as path-breaking institutions that were to be renewed by each new generation. 108 This first vision introduced the constitution as an event, a novelty, and a denial of past times that characterized constituent power as a political power immune from the past and able to fully rewrite the basic social compact. This was of course a very modern and progressive time: a revolutionary present with a future that might begin. At the same time, to be a temporal and enduring structure of expectations, the constitution needed to exceed the present and proclaim itself as a time-binding and synchronizing coupling between politics and law. Furthermore, if it has to work as an established rule of the game,

105. Id. at 384 .

106. Id. at 405 .

107. Koselleck, supra note 2, at 126.

108. See generally ANTONIO NEGRI \& MICHAEL HARDT, COMMONWEALTH (2011). 
written law is conceived as if its norms could bind and thereby coordinate social and political actors. As the higher law, the constitution is supposed to foresee the future for the sake of channeling the operations of state authority, and it should aspire to do so for an indefinite time.

For constitutions, time is out of joint! Its flexibility collides with its stability. To change or not to change: this is the problem! The early debates on modern constitutions are full of these clashes between divergent values. Stephen Holmes has a clear image of this paradox in his famous book Passions and Constraint, where he defines the solution as the choice of constitutional precommitment or the practice of self-binding or self-incapacitation, in the present, of a collectivity. For sure, this highlights another temporal paradox. ${ }^{109}$ The question is well known: Why should a constitutional framework, ratified long ago, exert such an enormous power over the lives of present-day citizens? Why should we accept the contemporaneity of the noncontemporaneous? Why should we accept a past that does not want to pass?

In modern liberal theory, this problem is framed as a possible tension between constitutionalism and democracy or constituted and constituting power. From the point of view of democracy, a constitution is a collective device with the (negative) function of eliminating certain decisions (future possibilities) from the democratic process or limiting the power of government. Citizens need a constitution just as Ulysses needed to be bound to his mast. Before the very idea of constitutionalism was equated with this limiting vision, a huge debate took place for almost two centuries (from the eighteenth to the twentieth century).

In the beginning of the debate about constitutions, from David Hume to Thomas Paine or Thomas Jefferson to Alexander Hamilton and James Madison, the general idea was against the time-binding power of constitutions. In a nutshell, a founding generation could never commit its successors to a fixed constitutional scheme. The positive value was attached to the possible alterations of any law. Among customary arguments, the principle was that no father can rightfully bind his sons. Antitraditionalism, antipatriarchalism, and the denial of inherited goods and properties were the building blocks of the debate over constitutions. For Paine, democracy was the rule of the living and a war against the past: nobility was no-ability. ${ }^{110}$ The past must not flood the

109. Holmes, supra note 17. See generally Stephen Holmes, Precommitment and the Paradox of Democracy, in CONSTITUTIONALISM AND DEMOCRACY 195 (Jon Elster \& Rune Slagstad eds., 1988). All the next argumentations are based on that essay.

110. Thomas Paine, The Rights of Man in THE LIFE AND MAJOR WRITINGS OF ThOMAS PAINE 251 (1961). 
present and the future, exactly as it cannot happen for the protestant contractual marriage. Marriage was an ongoing negation of the possibility of divorce: the future was a viable horizon opened up by negation of positive possibilities. The only valid consent was the consent of the living, i.e. the consent of the present. Thomas Jefferson declared the self-sufficiency of any generation, and believed that no possible Fatherland was able to "compact" the living, the dead, and the unborn. As Holmes underlines, Jefferson went so far as to deny all ordinary assumptions about historical continuity and, thus, national identity. Each generation is as independent as the generation it precedes. That is why national constitutional plebiscites should be held every twenty or thirty years.

The whole debate was funneled by the new semantic of the modern sciences, the positivization of law and all other forms of temporalization of complexity. Another problematic semantic was that of the early nation-state, with its ideals of popular sovereignty, individualistic citizenship, and immunization from state powers. Here again, we find a problem of identity-that is of temporal continuity. If medieval "constitutions" were thought of as contracts between the king and the various estates considered as separate parties, modern constitutions are typically intended as legal frameworks that "the people" give themselves (with all the well-known paradoxes of the "present absence" of the People as constituent power). A binding promise requires two parties and cannot be performed by one party alone.

Within the temporal frame of "presentism," constitutional theory was unable to make progress. If it is impossible to bind ourselves in the present, no constitution is logically possible, simply because nonreal identity is possible. Identity is a form that binds the past with the future in an enduring present. How was it then possible to overcome the prohibition against one generation binding the next and then the impossibility of an individual (a collective we) making a binding promise to himself (or themselves)? As usual, the solution came from the secularization of a theological Roman Catholic metaphorology-another temporal solution to be sure. ${ }^{111}$ Bootstrapping was not yet possible, so the only solution was to attach the constitution to an external enforcer: externalize your problems and let God do the rest! But this simple external solution was disabled because of the emerging semantics of auto-referentiality, which prohibited any heteronomy: what was needed was a self-limiting image.

111. See generally Francis OAKLEY, OMNIPOTENCE, COVENANT, AND ORDER: AN EXCURSION IN THE HISTORY OF IDEAS FROM ABELARD TO LEIBNIZ (1984). 
Of course the omnipotence of a self-binding God is better if internally auto-differentiated. Jean Bodin was the first to adopt the theological argument of a God able to commit himself. ${ }^{112}$ Surprisingly enough, the theoretician of absolute sovereignty was also the father of positive constitutionalism. Holmes sums up this constitutional argumentation in such a way: "[C]onstitutional restrictions are less limits on, than expressions of, sovereign freedom and power." 113 From Bodin to Madison and beyond, constitutional theorists describe the function of constitutions not only as limiting power but also as creating and assigning it to cement and secure the collective "we," to establish and activate democracy. ${ }^{114}$ And with Article V, the framers of the U.S. Constitution found a new way to change it by making the amendment (self-modification) process complicated and time-consuming. The problem was, as usual, tapped in the core of the constitution, within its very identity: to be a legal-political frame for a collective and self-constituting "we." 115 From this point of view, it is simple to understand the basic idea of limiting the power of any given majority to grant power to all future majorities. The common metaphors of checking, blocking, limiting, and dividing powers prevent the majority from abusing its power. This is also why the figure of Ulysses binding himself is not enough-he did not constitute himself! When constitution makers attempt to bind the future they are not simply trying to exercise control or foreclose options: they create and open unprecedented possibilities that would otherwise lie beyond reach. And the most important possibility is the "constitutional pre-commitment," the absolute decision to avoid self-destruction or self-disconstitution.

From a temporal point of view, constitutions regulate the constitutional check on ordinary law and in what ways the latter may exempt itself from the rule that new law breaks old. This represented a paradoxical shift from the past to the future as the pivotal temporal reference for the law:

[T] he constitution also ended the old law's openness to the past and replaced it with openness to the future. This means that arguments based on historical claims

112. JEAN Bodin The SiX BOOKS OF COMMONWEALE I, 10, 162 (1962).

113. HOLMES, supra note 17 , at 151 (emphasis removed).

114. For an introduction to the issue of corporate agents, see CHRISTIAN LIST \& PHILIP Pettit, Group Agency: The Possibility, Design, and Status of Corporate Agents (2011).

115. Riccardo Prandini, Reflexive Social Subjectivities, in ENGAGING WITH THE WoRLD: AGENCY, INSTITUTIONS, HistoriCAL FoRMATIONS 50-77 (Margaret S. Archer \& Andrea M. Maccarini eds., 2013). 
also had to be measured against the constitution, and conversely that the constitution normalized the procedure of the ongoing change of law. To achieve this, constitutions prescribe legislation, which is to be negotiated by parliament and to be formed juridically. ${ }^{116}$

The legal system generates a mechanism, secured by constitutional self-exemption, to pronounce itself illegal. Every norm could be unconstitutional, except for the constitution. As a consequence, the institution that can declare the unconstitutionality of all the statutes should perform a judicial function, not an executive or a legislative one. The separation of powers is a solution to the problem that emerged only when all the laws became positivized and alterable at will. The constitution must be exempted from the usual procedures applied to change the law, but, at the same time, changing and updating the constitution becomes more and more relevant and can be achieved only by interpretation. From the legal perspective, a constitution is a (positive) basic statute that needs to be interpreted and applied. It includes values as general points of interpretative reference and as rules for the closure of an otherwise ever-open horizon for argumentation. From a political point of view, the focal point concerns sovereignty-that is how to avoid arbitrariness at the top of the system and how to bind sovereignty to its communicated promises.

Constitutional interpretations increasingly has become a political issue. Trying to decide changes reveals a number of different values in the constitutional text and no radical rules for conflicts between them. It is precisely here that the operative closure of the two systems (politics and law) is clearly visible. Political actors search for and find political arguments: the legal system decides if the arguments are legally fitting. Values, value programs, and political utopias strike again, so that whereas value concepts have gone out of fashion everywhere else, "they can still be found in the decision-making of the Constitutional Court-and in the commitments of the programmes of political parties."117 Nevertheless, the problem still remains on the ground because the prohibition on changing the law could be changed by law indefinitely. "This problem cannot be contained normatively[,] [i]t has to be [G]ödelized in the direction of politics." 118

This Gödelization, in turn, reveals that the modern equilibrium of constitutional change is, again, deranged by post-modern processes. One of the most relevant of such processes is social acceleration, which risks

116. LUHMANN, supra note 24 , at 406 .

117. Id. at 121 .

118. Id. at 126 (emphasis removed). 
favoring insufficiently democratic mechanisms for constitutional change or adaptation. Not only is the pace of change requested by high-speed society increasing, but also the very idea of maintaining a stable constitutional identity turns out to be "improbable and out-of-fashion." All of the four typical ways of constitutional change are at risk. The "dualistic" system of formal amendment, based on the separation between ordinary lawmaking and higher constitutional legislation, ensures a higher level of democratic legitimacy than the one found in ordinary decision-making, but this system has to proceed slowly and deliberately to decelerate political debates in order to ensure their reasonable and sound character. The results, in the age of acceleration, are inefficiency, impossibility to change, and dramatic desynchronization between law and politics. Judicial review by constitutional courts is much more adapted to societal acceleration, but high-speed societal processes tend to transform constitutional courts into constitutional assemblies in permanent session. The pressures to modify constitutional principles in order to adapt them to social change push the courts to conflate legal interpretation (based on the principle of "stare decisis") with sheer legal creativity. ${ }^{119}$ This conflation leads toward the deconstruction of the difference between law (interpretation) and politics (modification) and, consequently, toward a democratic deficit. Constitutional change via elected legislatures could be faster than the dualistic system and is actually set forward as a proposal for the new constitution. ${ }^{120}$ But again, there is a risk of losing the distinction between constitutional and ordinary law. Furthermore, this mechanism needs a very reasonable and skilled assembly, and this is not always the case. An example of this device, which might be useful for post-sovereign constitutions, is the two-stage process where initial round table negotiations with power holders establish the grand rules for an elected assembly writing the new constitution (overviewed by a constitutional court). ${ }^{121}$ This process, however, seems to take a lot of time. Finally, executive-driven constitutional change appears to be very fast but much too unbalanced in terms of power. The rhetoric of "agere us deliberare" (to act versus to deliberate) is not easily controllable; moreover, the executive is not always simple and unitary.

119. See SCHEUERMAN, supra note 69.

120. See generally Stephen Holmes \& Cass R. Sunstein, The Politics of Constitutional Revision in Eastern Europe, in RESPONDING TO IMPERFECTION: THE THEORY AND PRACTICE OF CONSTITUTIONAL AMENDMENT 275, 294-99 (Sanford Levinson ed., 1995) (proposing a legislature-dominated system of constitutional amendment in Eastern Europe based on the underlying unique circumstances in that region's transition from socialism to constitutional democracy).

121. See generally Andrew Arato, Multi-Track Constitutionalism Beyond Carl Schmitt, 18 Constellations 324 (2011). 
The problems arising from social acceleration lead us again toward societal constitutionalism. What does it mean for the emerging constitutional processes, concerning global, functionally differentiated social spheres, to enter the age of speed? What kind of lesson can provide us with reflections on state constitutions? I want to suggest three new issues: 1) the pointlessness of representing constitutional processes as driven by unitary and simple stable actors; 2) the new and increasing relevance of international courts or bodies of arbitration in starting up constitutional processes; and 3) the growing importance of human rights in the constitutional framing of global social systems.

\section{EXAMPLES OF CONSTITUTIONALISM IN A HIGH-SPEED SOCIETY: Post-SOVEREIGN CONSTITUENT POWERS, DisPUTE RESOlutions COURTS, AND HUMAN RIGHTS}

In this final section, I would like to show in a very tentative and synthetic way some insights that derive from shifting the analytical frame of reference from spatial to temporal metaphors. First, I want to stress a very important point in the debate on societal constitutionalism, which remains latent but pervasive. It is quite clear that many scholars prefer to frame the debate via the concept of "constitutionalization" instead of "constitution." In my opinion, this preference depends on the temporalization of society. For sure, framing the normative and jus-generative processes concerning the self-limitation - through secondary ruling of primary rules-of global social subsystems directly into the concept of constitution could be a little misleading. This is neither because of old, obsolete, and methodological nationalism nor because of the well-known criticism about the absence of a clear and legitimate polity, authoritative organizations, and centers of powers. The point is, first, that the new processes of global societal self-constitutionalization seem to institutionalize faster but in different ways than the modern ones. In those cases, some of the relevant features of modern state constitutions seem to be absent. Some examples of those deficits are the absence of an ultimate "We the People" of clear and stable stakeholders engaging in the constitutional processes of representative executive and legislative bodies. Second, one should not take for granted that this kind of constitutionalization necessarily emerges "inside" organizations. It can be said that global constitutionalism may also develop when forced and compelled from its "outside," that is, from the different environments of law and politics. We could talk of "constitutionalism without constitutions" exactly as it is possible to talk about "constitutions 
without constitutionalism," for instance in the case of China. ${ }^{122}$ To argue this point, I select only three aspects of the ongoing processes of global constitutionalization, but I am sure that framing the current debate within this new interpretative key (temporalization) would enable us to find many other examples or to accomplish many case studies.

The first example has to do with the growing improbability that new, self-constituting polities (the self-constituting collectivities or "subjectivities") may find their legitimacy in their past (it does not matter whether real of fictional), and/or from the problematic presence of "We the People." Not only does the new pouvoir constituant (constituent power) not refer to any past legacy, but it tends to project its self-constitution into the future, allowing a variety of interested actors to connect/not connect to a "center of political gravity" that we can call a "political hub" (and not a representative unity at all). We can observe "strange attractors," bundles of interests/identities that are never completely closed and do not rule out the possibility that multiple actors will connect to and participate, for a short or long time, with an ever-constituting and operating collective self. ${ }^{123}$

The clear and well-defined political unity of government is replaced by a fuzzy and nebulous "magnetic field" constituted by different and networked actors that the field finds useful to connect to a hub. In an evolutionary perspective, this means that the clear origin of constitutions is replaced by situations in which organizations that are already following legal norms find it useful to regulate these operative rules with constitutive metarules. An interesting and clear example of this "escape from the present" of representative pouvoir constituant is given by the work of Andrew Arato, concerning what he calls "past-sovereign constitution making."124 Arato began studying the drafting of constitutions in Hungary after the liberation of East European countries from Soviet dominance in 1989-90.125 He framed postsovereign constitutions (not only in Eastern Europe, but also in

122. E.g., Butlding Constitutionalism in China (Stéphanie Balme \& Michael W. Dowdle eds., 2009); Antonin Cohen, Constitutionalism Without Constitution: Transnational Elites Between Political Mobilization and Legal Expertise in the Making of a Constitution for Europe (1940s-1960s), 32 LAW \& SOC. INQUIRY 109 (2007) (analyzing how legal elites have altered and continue to alter the European transnational order).

123. E.g., David Sciulli, Societal Constitutionalism: Procedural Legality and Legitimation in Global and Civil Society, in LEGALITY AND LEGITIMACY: NORMATIVE AND SOCIOLOGICAL APPROACHES 103 (Chris Thornhill \& Samantha Ashenden eds., 2010) (discussing the constitutional relevance of the many and different collegial formations, reflection centers, and social movements in civil society).

124. Andrew Arato, Post-Sovereign Constitution-Making and Its Pathology in Iraq, 15 N.Y.U. L. REV., 536-55 (2006-2007).

125. ANDREW ARATO, CIVIL SOCIETY, CONSTITUTION AND LEGITIMACY (1999). 
South Africa, Spain, and other countries) as path-breaking political innovations because of the postmodern social mechanism of "negotiate transitions" from dictatorship to a democratic regime. ${ }^{126}$ As he underlined, the year 1989 did produce something dramatically new: a political paradigm of radical transformation yielding a historically new, superior model of constitutional creation beyond the revolutionary democratic European models.

The postsovereign model entails a two-stage process of transition from dictatorship to constitutional democracy. The first stage concerns the organization of thick round table negotiations attended by both the previous power holders and the present and future significant social voices (all present and future stakeholders). This first collective negotiation, which has a place without the fiction of a "we" composed by equal individuals, establishes the ground or constitutive rules (usually an interim constitution) for the second stage, where an elected assembly actually writes the new, ultimate constitution. Here, constituent power is not embodied in a single organ or instance endowed with the plenitude of powers but in a host of different and already constituted "parts" of the society, negotiating for a new and plural constituted power. Between the two stages, the constitutional court gives significant overview to the process by ensuring that the elected constitutional assembly abides by the ground rules decided during round table talks. ${ }^{127}$

It is worth noting that at least two components play a fundamental role in the drafting process: drafting the interim constitution (the round table of major political forces) and the drafting the final document, which is always conducted by a freely elected body that should not be called a constitutional assembly. The drafting process should be characterized by broad social inclusion, equality, transparency, and publicity. With this mechanism, constitutionalism abandons the mythology of "We the People" as the ultimate sovereign authority able to speak in an unmediated form and reactivates the model of a constitution created and enacted by different and plural actors. The result is a deconstruction of any "part" claiming to represent (again the present) the people. As Arato declares,

[w] hat in the single-stage model is a single set of utterances, made by one speaker(s) in the name of another subject that never speaks, becomes two, with two acting subjects, in two distinct stages, with

126. ANDREW ARATO, CONSTITUTION MAKING UNDER OCCUPATION (2009).

127. Andrew Arato, Conventions, Constituent Assemblies, and Round Tables: Models, Principles and Elements of Democratic Constitution-Making, 1 Global ConstTtutionalism 173-200 (2012). 
ascending but never complete legitimacy. Unlike the speaker of the classical populist model, the speaker of neither stage here is able to fully identify itself with the popular sovereign ... The speaker(s) who write an interim constitution speak at the same time directly in the name of political organizations and establish a process by which a democratically authorized set of speaker(s) can be elected. ${ }^{228}$

In this sense, some pouvoir constitue is always part of the constituant. The entire model based on the idea of an actor acting for a principal is deconstructed, as in the model of a direct-deliberative poliarchy elaborated by Charles Sabel. ${ }^{229}$ The past, which is the ready-made, reenters the present and both open up possibilities for the future.

It is worth noting that postsovereign constitutions (the model I would generalize to societal constitutionalism), characterized as they are by the cooperation of many collective (and not individual) actors and some (already made) powers, usually operate with different "proceedings" to reconstruct their self-constituting and pluralistic identity. Here, we can find the (always undervalued) "political" core of societal constitutionalism. It is fundamental to observe the constitutional process from a double point of observation. From one point of view, the function of law is just to guarantee the certainty of expectations (to code every communication using the legal-illegal code); the system is invariant only in the structural form of its code: it is always eager to be adapted or transformed into the self-produced uncertainty of an open future.130 Only the code can produce the uncertainty in which the proceedings feed. The proceedings use uncertainties to call for contributions, encourage participation, offer opportunities, and thus invite participants to cooperate, that is, to acknowledge acceptance until the participants finally become prisoners of their own participation with only a very slight prospect of contesting the legitimacy of the proceedings after they have run their course.

128. Andrew Arato, Redeeming the Still Redeemable: Post Sovereign Constitution Making, 22 InT'L. J. POL. CUlTURE SOC'Y 427, 439 (2009).

129. Charles F. Sabel \& Oliver Gerstenberg, Constitutionalising an Overlapping Consensus: The ECJ and the Emergence of a Coordinate Constitutional Order, 16 EUR. L.J. 511, 543-50 (2010) (connecting the "jurisprudence of mutual monitoring to . . to the idea of deliberative polyarchy").

130. About this form of proceedings and the opening of future, see LUHMANN, supra note 65. 
From the other point of view, the function of politics is to ensure the efficient implementation of collectively binding decisions. Power is ultimately the generalized capacity of an organization to establish and enforce collectively binding decisions. ${ }^{131}$ Power tries to bring together opinions in such a way that collectively binding decisions can be made. Using legal procedures, the political system can futurize itself so it can gain time and be able to operate before definitive decisions are taken. Here again, we can observe the structural coupling between politics and law. For the political system, law is an instrument for the facilitation and realization of its goals and plans. In the age of globalization and acceleration, a legal system is increasingly a precondition for the making of (nonstate) policies. At the same time, the system of law can develop only if cooperation is secured politically and the enforceability of decisions is secured elsewhere.

An example of a postsovereign constitution sustained by legal-political procedures is brilliantly presented by Jaye Ellis in his work, Forest Stewardship or the Marine Stewardship Council.132 The Council is "constituted" by networks of governance actors including scientists, governments, media, industry actors, and members of civil society. The Council's goal is to deliver its certification programs in the environment of the consumers. The Council works to create a present future where governance structures and decision-making processes are legitimate but not democratically representative, and it operates to render its future presents as transparent, responsive, accountable, and accessible to affected actors as possible. The Council's interest is to link the present networks with other regimes to build up meta networks. The authority of these organizations is not dependent on formal legislative enactment, on pregiven constitutional provisions, or on elections (the basic principles of modern political representativeness). The organizations construct their legitimacy as collective organizations through the inclusion of stakeholders called on to comment on draft legislations. The point I want to underline, and which I think might be generalized in the majority of cases concerning societal constitutionalism, is that the pluralistic and internally heterogeneous "we" self-constitute themselves "in time," permitting their stakeholders to interact and participate in the proceedings and create various channels for feedback and openness for a range of different voices. ${ }^{133}$

131. Talcott Parsons, On the Concept of Political Power, Proceedings of the American Philosophical Society 107 (1963).

132. See Jay Ellis, Constitutionalization of Nongovernmental Certification Programs, 20 IND. J. GLOBAL LEGAL STUD. 1035 (2013).

133. It would be interesting to open a dialogue with Hans Lindahl, concerning the self-constitution of a collective "We." In general, I fully agree with him on the relevance of the 
They maintain their future open for accessing and connecting to decision-making fora, critique fora, third-party observations, consumer opinions, and state-based authorities. In each and every one of these processes and structures, the basic goal is to render the actions of "government" influenced, calculable, and open for every actor to participate. The higher value is not the definitive character of decisions and norms but their "determinability" in the future presents. That is why Ellis can conclude his paper by affirming that "at the present, the emphasis is on legitimacy and credibility rather than validity, and the rule of law is only weakly present." 134 From my point of view, this is exactly what happened with the temporalization of the validity of law. Politics operate here to make the rules respectable and credible, even if not yet formally valid. And the polity of this council is opened to access and recess. 135

The same is true for the case study presented by Moritz Renner about the International Accounting Standards Board (IASB). ${ }^{136}$ This Board, which produces the International Financial Reporting Standard (IFRS), is overseen by the IFRS foundation, which has given itself a constitution. This constitution foresees that the IASB shall publish an exposure draft on all projects and normally publish a discussion document for public comment on major projects in accordance with procedures approved by the trustees. After a public consultation process has been made, the standards are finalized and pipelined to the jurisdictional adoption process. Renner explains that in a typical consultation procedure, comment letters and commentaries are issued by hundreds of stakeholders, including legal corporations, private and public business associations, nongovernmental organizations (NGOs), public authorities, and academics. The relevant point is that the

self-constitutive process giving birth to a new collective. But I would like to underline, deeper than Lindahl, the contingency of the constitutive process and the possibility to reverse it. It is not possible to take for granted that, once a "We" is constituted, it will remain the same forever. The identity of a collective is "temporalized," and its membership could change at any time. For this argumentation, see Hans Lindahl, We and Cyberlaw: The Spatial Unity of Constitutional Orders, 20 IND. J. GLOBAL LEGAL STUD. 697 (2013); Riccardo Prandini, The Morphogenesis of Constitutionalism, in THE TWILIGHT OF CONSTITUTIONALISM?, supra note 1, at 309 (arguing that it is necessary to talk about processes of constitutional morphogenesis which give rise to new forms or maintain old forms).

134. Ellis, supra note 132.

135. It seems to me that in his contribution in this Issue, Larry Catà Backer too underlines the relevance of introducing a dynamic element to explain societal constitutionalism. He clearly recognizes that self-referential governance communities and collegial institutions may change and need to work out and maintain their identities "in time." See Larry Catà Backer, Transnational Corporations' Outward Expression of Inward Self-Constitution: The Enforcement of Human Rights by Apple, Inc., 20 IND. J. GLOBAL LEGAL STUD. 805 (2013).

136. Renner, supra note 41. 
stakeholders participating in the proceeding present themselves as representative. That is why Renner concludes his paper by saying that the public consultation process can thus be considered a reflection of an emerging (and ongoing) political discourse on the global stage.

What is at stake here, in the present future of IASB, is neither the construction of a permanent and immutable authority, nor a definitive and everlasting standard, nor even the ultimate definition of the organization's members. Instead, what is needed is only the ongoing research and realization of temporary "agreements," or what Luhmann calls "understandings," i.e. negotiated provisos that can be relied upon for a given time.

They do not imply consensus, nor do they represent reasonable or even correct solutions to problems... Understandings have one big advantage over the claims of authority: they cannot be discredited but must be constantly renegotiated ... Negotiations can then be defined as an attempt to increase uncertainty to the point that the only option that remains is understanding one another. ${ }^{137}$

The relevance of the contingency and the temporal fluidity of ongoing constitutional processes is also stressed by Chris Thornhill in his most recent works. ${ }^{138}$ In a high-speed society the need of juridification grows, and the new globalized or international polities have to generate legitimacy in a rapidly iterated manner. By referring to rights, emerging polities are able to restore, together with legality, simple forms of legitimacy. The function of those globally localized political systems-deciding in a collectively binding way so as to include as many new citizens as possible-needs to be more flexible. Thornhill affirms that it is the system of law, with its internal reference to rights, that enables the building of temporary political structures. In contemporary society, highly abstracted rights are the response to the rising demands for highly contingent inclusion. Political inclusion needs to be performed at a very high level of abstraction, contingency, and precarious variability. This leading function of law in shaping politics explains why political objectives can be fluidly allocated to a variety of institutions, and various organizations can assume constituted status as distinctively public or political. Thus, it is rights that constitute actors

137. LUHMANN, supra note 56 , at $69-70$.

138. E.g., Chris Thornhill, Re-Conceiving Rights Revolutions: The Persistence of a Sociological Deficit in Theories of Rights, 31 ZEITSCHRIFT FÜR RECHTSSOZIOLOGIE [JOURNAL OF SOCIOLOGY OF LAW] 177 (2010) (Ger.). 
and organizations as political and not the other way around. Legislation is replaced by jurisdiction and judicialization, legislatures by unelected and variable actors, public parliaments by private courts, and states by networked actors. Transnational rights have assumed the polity-building functions once accorded to the sovereign. The modern semantics and structures prizing stability and certainty are replaced by the values of contingency and determinability.

The second example has to do with the growing relevance of (not national) courts as "centers" and "injectors" of societal constitutionalization. ${ }^{139}$ Courts are not only relevant because they anticipate the consensus of the actors involved in dispute resolution connecting them to a legal and self-sustaining proceeding; they are decisive because only in court is it possible to make rapid decisions about dispute resolution, thus speeding up the mutation of the present future uncertainties into a more certain future present. In that sense, decision-making is a technique to defuturize time. As we have seen in a previous paragraph, with the acceleration of society and the rushed and hasty new temporal semantic of "deadlines," the function of courts has changed. From the second half of the sixteenth century, the role played by legislation increased. At that time, legislation was conceived as a sovereign "principal," whereas courts were understood as "agents" charged with executing legislation. But at the beginning of the twentieth century, this well-established hierarchy changed, and judge-made law became accepted as a source of law of a special kind. The relationship between legislation and judicial review became dangerously circular. The last "fiction" that sustained the hierarchy in which "the judge is bound to the law" collapses because of the autoreferential closure of the legal system: the legislator is also bound to law.

Luhmann helps us to understand this metamorphosis in term of forms of social differentiation. ${ }^{140}$ The internal differentiation of the legal system cannot be conceived as a hierarchy or a segmental system. In conditions of global, social, and temporal complexity, it takes the center-periphery form. Courts occupy the center as banks do in the economic system. Nowadays, it is parliaments, lawyers, and contracts that occupy the periphery of the system; this is because they are not

139. See SCHEUERMAN, supra note 69, at 71-105. See generally JEAN L. COHEN, GLOBALIZATION AND SOVEREIGNTY: RETHINKING LEGALITY, LEGITIMACY, AND CONSTITUTIONALISM (2012); INTERNATIONAL JUDICIAL LAWMAKING: ON PUBLIC AUTHORITY AND Democratic Legitimation in Global Governance (Armin von Bogdandy \& Ingo Venzke eds., 2012).

140. See LUHMANN, supra note 24, at 274-305 (discussing the position of courts in the legal system). 
subjected to compulsory decision-making. Only courts have to decide to reduce the uncertainties of law. And that is why the periphery is particularly suited as a point of contact with other subsystems. This is the new space where legal pluralism can evolve. As Alec Stone Sweet explains, the various international or global courts (e.g. the Appellate Body of the World Trade Organization, the European Court of Justice of the European Union, and the European Court of Human Rights), conceived as legal "zone of discretion," are more authoritative than most national courts. Stone Sweet conceptualizes these zones as determined by the sum of powers delegated to, and possessed by, the court as a result of its own rulemaking through the building of precedents minus the sum of control instruments available for use by nonjudicial authorities to shape or to counter the outcomes of the court's performance. With these powers, the courts "will come to exercise more influence over the evolution of the [new global] polity." 141 Of course, the distinction between center and periphery does not mean a hierarchy of value or a new source of law-the courts cannot give orders to the legislators. The relevance of courts depends instead on "temporal urgency" and on the duty to take decisions that may resolve, in the present time, disputes. Courts have to decide what is legal or illegal and cannot avoid upholding justice. ${ }^{142}$ The expected norm is the prohibition of the denial of justice. It is worth noting that only courts are obliged to transform indeterminacy into determinacy and only courts have to fictitiously reconstruct the availability of principles where necessary. This growing relevance of courts was fueled by the emergence of constitutions that placed them in subverting positions because the courts now have to decide on the constitutionality of legislative procedures and outputs. The other function of courts, to supervise the consistency of legal decisions by means of interpretation and judicial review, is equally relevant in high-speed society because it arranges a special second-order observation of law that decides, step-by-step and moment-by-moment, its validity.

The third and final example of the relevance of time and acceleration in processes of global constitutionalization is given by the growing importance of human rights. The argument is linear: "There cannot be any doubt that the global society has a legal order, even if it does not have a central legislation and decision-making. Among the most important indicators of a global legal system is the increasing

141. Alec Stone Sweet, Constitutionalism, Legal Pluralism, and International Regimes, 16 IND. J. GLOBAL LEGAL STUD. 621,640 (2009).

142. See Christopher Thornhill, A Sociology of Constituent Power: The Political Code of Transnational Societal Constitutions, 20 IND. J. GLOBAL LEGAL STUD. 551 (2013). 
attention paid to the violation of human rights."143 When does this central relevance begin? It is due to the fact that those violations seem to be "immediately" illegal, without any time-consuming practices to start assessing them. What one can observe is a very fast way of generating norms on the basis of scandals and incidents. As Luhmann notes, the almost self-evident force of human rights accelerates the emergence of shared and valid norms at maximum overdrive. ${ }^{144}$

Last but not least, "[o]ne who reacts indignantly and expresses counterfactual expectations in such cases does not have to reckon with dissent-almost as though the meaning of the norm was vouched for by sacred powers." 145 From this point of view, human rights can be conceived as self-constructed "external" reference points for the constitutionalization of global society. In a society where everything becomes contingent and differently possible so that the past is irrelevant for deciding what is "right" and "suitable" and the future remains unknown, global society needs to find something unconditional. This is the function of law as the immune system of society for intercepting and neutralizing unpredicted disturbances, which develop in the area of structural couplings. ${ }^{146}$ A system cannot have countermeasures ready for a point-to-point defense. The immune system registers internal conflicts and develops case-by-case solutions that then can be generalized. Generalizations are normative rules for conflict resolution that uses their time-binding effect to securely maintain the future just when they are factually disappointed.

"[T] he formulation of rules is like the generation of antibodies for specific cases." 147 Here, the cases concern the violations of human dignity, where asymmetries of roles (tolerated inside functional subsystems) become fixed and are treated as irreversible by a reference to an outside. 148 This irreversible negativity needs to be contrasted with an irreversible positivity: the idea that human dignity is "forever" temporally irreversible, "unconditional," not time-dependent, and out of time. Actually, this "forever" means the necessity to keep the future open for the diverse autopoietic reproductions of respective subsystems. Human rights are simultaneously enabling and constraining because "[n]o distribution, no classification, and above all no political sorting of

143. LUHMANN, supra note 24 , at $481-82$.

144. See Niklas Luhmann, Are There Still Indispensable Norms in Our Society?, 14 SOZIALE Systeme 18, 26 (2008).

145. Luhmann, supra note 25 , at 33 .

146. Id. at $475-79$.

147. Id. at 477.

148. See LuhmanN, supra note 25 , at $486-87$. 
people can limit the future."149 The future must not begin because it has to remain open to possibilities. The increasingly crucial function played by human rights in the process of global constitutionalization might be interpreted as the necessary presence of "values" in the environment of the law's system. The value of human dignity may represent the transcendent formula of contingency (a kind of "stop rule") "invented" to contrast the uncontrollable releasing of new and unexpected social powers and immunize society against them: ${ }^{150}$ the impossible condition of possibility for law (the "inconditionality" that fund every conditioned laws).

It is not a mere coincidence that as an "autological" text, a constitution always needs to be interpreted bilinguistically, from the "inside" and "outside" of the coupling, as something unconditional over and above everything that is conditional, something necessary beyond everything that is contingent. We speak of basic rights when we refer to justiciability; we speak of basic values when we need to legitimize the legal system:

Reference to justiciability corresponds with the central
position of the courts in the legal system. The semantics
of values makes it clear that the meaning of the validity
of law is not exhausted but can claim to have a higher
level of meaning which lies beyond fluctuating
validities-in modern terms, civil society-in which the
necessary foundations can be found. ${ }^{151}$

Again, courts and human rights - the horizontal and vertical layers of constitutions-are mediated by new (self)constituent-constituted societal powers, where consensus has to be created by means of "political" argumentations. In the end, constitutionalism and constitutions remain necessary as fictive eigenvalues permitting the structural coupling between (societal) law and politics. But referring to the needful eigenvalues does not mean the "end of history"; it offers no guarantees against the growing and never-ending production of social

149. Id. at 135 .

150. E.g., JACQUES DERRIDA \& ANNE DUFOURMANTELle, OF HosPiTALiTY (Rachel Bowlby trans., 2000); Riccardo Prandini, Re-vealing (vs Un-veiling) Justice. Riflessioni sullenigma della giustizia trans-immanente [Reflections on the Enigma of Transnational Justice], in SOZIOLOGISCHE JURISPRUDENZ: FESTSCHRIFT FÜR GUNTHER TEUBNER ZUM 65. GEBURTSTAG [SOCIOLOGICAL JURISPRUDENCE. COMMEMORATTVE PUBLICATION FOR GUNTHER TEUBNER'S 65TH BLRTHDAY], supra note 38, at 309; Gunther Teubner, Self-subversive Justice: Contingency or Transcendence Formula of Law?, 72 MoD. L. REV. 1, 3 (2009) (arguing that justice is "the subversive practice $]$ of law's self-transcendence.").

151. LUHMANN, supra note 24 , at 446 . 
risks and dangers: "What remains is the replacement of the known past with the unknown future as a constant, continuously operating premiss. What remains is the ongoing creation of contingencies as stable eigenvalues, as recursively renewed values of the legal system." 152 In the age of high-speed societies, constitutions are necessary and increasingly improbable. Constitutions oscillate between the value of stability (duration) and instability (change). They need to be maintained but increasingly amended. They have to freeze the future (time-binding function) but only to keep it open. They need to overcome their state-nation's embeddedness, only to generalize their features to other self-constituent "we." In this shaky situation, global civil constitutions, propelled by a huge production of rights, may develop into virtual social containers in which various collective polities could "connect" to operate legally and with political (collective) objectives. Here "political" means only with the ability to adopt binding decisions for a whatever self-constituting "we." In this sense the metacode of constitutionality could move from the permanent values of "inclusion/exclusion" toward the more flexible and contingent code of "connected/unconnected." This may change the idea of constitutionalism, shifting it from a spatial qualification to a temporal one. The decision to connect with this virtual legal space (and its constitutional tool box) may become a contingent decision. The only rule will be that if an actor decides to connect with the virtual constitution (the peculiar global regime), then he shall respect its rules and metarules. And this will be necessary to operate in a legal way together with other actors in a legalized social sphere. If the actor decides to disconnect, he shall do so, paying the price of operating outside the system with a growing difficulty to reaccess the virtual legal regime. 